
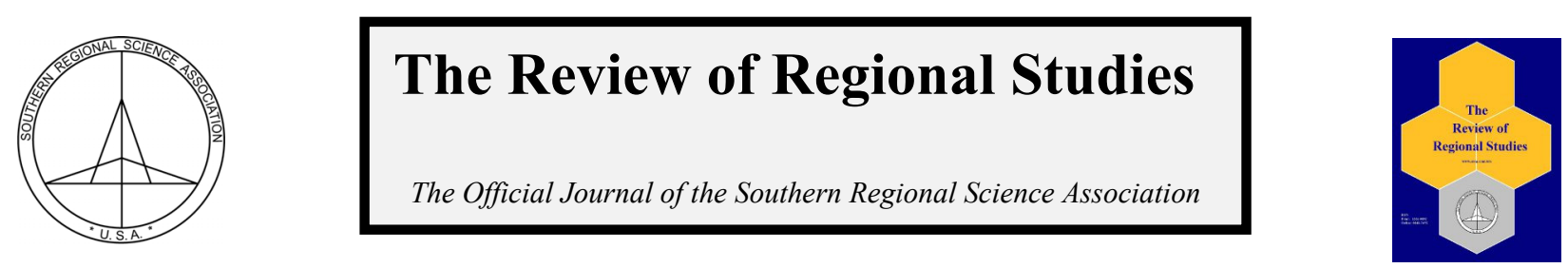

\title{
Diversification and Specialization of U.S. States*
}

\author{
Janet Koech and Mark A. Wynne
}

Federal Reserve Bank of Dallas, USA

\begin{abstract}
This paper documents the evolution of the international relationships of individual U.S. states along three dimensions: trade, migration, and finance. We examine how specialized or diversified state economies differ in terms of the products they export and with whom they trade, the origins of the immigrants who live in the state, and the origins of the foreign banks operating in the state. We show that states that are diversified along one of these dimensions are often quite specialized along others. New York is - perhaps, not surprisingly — the most diversified state in terms of global linkages.
\end{abstract}

Keywords: globalization, international trade, migration, bank assets, diversification, specialization

JEL Codes: F10, F16, F22, F30, G21, R23

\section{INTRODUCTION}

The tremendous growth of international trade over the past several decades has led to greater economic integration. World trade, composed of both nominal imports and exports, increased dramatically from about $\$ 100$ billion in 1950 to over $\$ 37$ trillion in 2014 . As a result of the increased trade flows, consumers around the world enjoy a broader selection of products. While increased international trade has spurred economic growth across the globe, increased interconnectedness means that the effects of economic slowdowns are also spread across geographical boundaries.

Focusing on just the United States, the growth of U.S. merchandise exports over the past two decades has been remarkable. From about $\$ 393$ billion in 1990 to over $\$ 1.6$ trillion in 2014, exports as a share of GDP have increased from 6.6 percent to 9.3 percent. ${ }^{1}$ At the level of the individual state, Texas exports more goods than any other U.S. state, accounting for about a fifth of total U.S. exports in 2014. Texas's exports in 2014 totaled \$288 billion, up 2.9 percent from 2013. From 2000 to 2014, Texas' real exports increased at an annual average rate of about 7 percent, faster than the nation's annual average rate of increase of 4 percent. Some of these exported goods are manufactured in the state, while others are produced in other states and shipped to Texas for consolidation in distribution centers and export to destination countries. ${ }^{2}$

\footnotetext{
${ }^{*}$ The authors thank the editor, two anonymous referees, and Latika Lagalo - their discussant at the 2015 Annual Meetings of the Southern Economic Association-for helpful comments and suggestions. The views expressed in this paper are those of the authors and do not necessarily reflect the views of the Federal Reserve Bank of Dallas or the Federal Reserve System.

Koech is an Assistant Economist, and Wynne is the Vice President and Associate Director of Research at the Federal Reserve Bank of Dallas, 2200 N. Pearl Street, Dallas, TX 75201. Corresponding Author: J. Koech E-mail: janet.koech@dal.frb.org

${ }^{1}$ Exports are reported in nominal terms.

${ }^{2}$ Origin of movement export series identify where the export journey begins, reflecting the transportation origin of exports. See http://www.census.gov/foreign-trade/aip/elom.html for more information
}

(C) Southern Regional Science Association 2017.

ISSN 1553-0892, 0048-749X (online)

www.srsa.org/rrs 
Though these ("re-export") goods are not produced in Texas, they have positive spillover effects in areas such as insurance, warehousing, and transportation, generating income and jobs in the state's economy.

Texas exports goods to over 180 foreign destinations. The state's largest trading partner is Mexico, which accounted for approximately 36 percent of all of Texas exports in 2014. Canada is a distant second and sat at 11 percent in 2014. Although Mexico remains the state's largest export market, it now receives a lesser share of the state's nominal exports than it did at the turn of the $21^{\text {st }}$ century. Texas's export share to Mexico declined from a peak of 46 percent in 2000 to 32 percent during the world trade collapse in 2008. Exports have been since gradually rebounding, with shares inching up to 36 percent in 2014, but still 10 percentage points below its peak. The lack of growth in exports to Mexico is partly due to rising export shares to other emerging markets such as China and Brazil. Exports to China increased 17 percent on average from 2000 to 2014, while those to Brazil expanded at an average annual rate of about 14 percent during that period. Emerging markets' demand for petroleum and coal products has boosted Texas exports.

The state's largest exports are petroleum and coal products, which represent 19 percent of total state exports, computers and electronics (17 percent), and chemicals (16 percent). The composition of Texas exports has changed over time. The state has diversified its economy away from oil and gas, following the oil price collapse and recession in the 1980s. By 2000, computers and electronics accounted for 29 percent of Texas exports, and petroleum and coal products had fallen to 4 percent. Since then, as a result of technological innovations in exploration and rising oil prices, the energy sector has reemerged as a major driver of growth.

In what follows, we address the following question: How diversified are the international trade linkages of Texas and other states? We approach this question from two angles. First, to what extent are Texas exports driven by exports to any given country? Given Texas's proximity to Mexico, we might expect that exports to Mexico are particularly important to the overall exports of Texas. Dependence on a few export partners and products can make exports and exporting states sensitive to developments in the recipient countries. Ideally, a state would export to a range of countries, with shares of trade roughly proportional to the importance of these countries in global economic activity. Likewise, Texas is often stereotyped as depending too heavily on a single sector-oil and gas - as a driver of growth and exports. Such sectorally focused dependence can leave a state vulnerable to shocks to those sectors.

We construct a number of simple measures of the degree to which the exports of Texas and other U.S. states are specialized or diversified by destination and by product. Importantly, we go beyond trade linkages to also examine two other dimensions of globalization, international migration and international finance. There are important synergies among all three dimensions of globalization: migration tends to promote trade and trade tends to promote international financial linkages. Just as Texas tends to trade heavily with Mexico, so too do the many immigrants who live in Texas come from Mexico. Geography and network effects seem to play a pivotal role in explaining these patterns.

Financial globalization is the third dimension of global linkages that matters. Arguably the world has seen greater changes in this dimension of globalization over the past quarter century than in the other two (Clemens, 2011). The recent global financial crisis would have taken a very different course were it not for the enormous increase in cross-border flows of 
capital in recent decades. However, this is the dimension of globalization for which we have the weakest data at the level of individual U.S. states. As a result, we simply report the little data that exist, and leave for future work the challenge of documenting more accurate measures of financial globalization at the state level.

Before proceeding, we note that the issue of whether international linkages - be they in the form of trade, migration, or investment - are beneficial to the home or host countries or states remains controversial in the public discourse, although the economics seem quite clear cut. Whereas professional economists tend to emphasize the gains from trade in the form of lower prices, increased product variety for consumers, and enhanced economic efficiency, the political debate tends to be driven by the fortunes of those who lose from the introduction of freer trade. In the 1980s, this took the form of concerns about the economic vitality of the "Rust Belt" as U.S. manufacturing faced increased international competition from countries like Japan and South Korea. ${ }^{3}$ In the early 1990s, concerns were voiced about the "giant sucking sound" that some feared would accompany the adoption of the North American Free Trade Agreement (NAFTA). Following the information technology revolution that kicked into high gear in the late 1990s, many service sector jobs that were previously considered safe from international competition started to move "offshore." With the integration of China and other large emerging market economies into the global economy in the $21^{\text {st }}$ century, attention shifted to the scale of the job losses in the U.S. and other advanced economies associated with the "China shock."

Likewise, the extent to which international migration has affected U.S. labor markets detrimentally has waxed and waned as an issue in the political discourse of the United States for decades if not centuries. All of these issues are reviewed at length elsewhere: Collins (1998) and Kletzer (2002) are good summaries of what we knew about job creation and destruction associated with international trade as of the turn of the century; Bhagwati and Blinder (2009) is a good summary of the debate on offshoring; Autor, Dorn and Hanson (2013) provide estimates of the job losses in the U.S. associated with the China shock; Borjas (2014) provides an overview of the literature on immigration and its effects on wages. We will not touch on these controversies directly in what follows. Rather, our analysis complements this work by highlighting the diversity of international linkages at the individual state level. While a more diverse set of trading partners, for example, will not prevent the job losses associated with international trade, it should, in principle, make employment in a state less exposed to developments in any one of its trading partners.

\section{RELATED LITERATURE}

There is a large literature on the international trade patterns of U.S. states. Cassey (2011) is a comprehensive survey of much of the work in the 1990s and 2000s. Coughlin and Cartwright (1987) examine the effectiveness of state export promotion efforts and actual state exports, finding that expenditures on export promotion do have their desired effects. Erickson and Hayward (1991) document international trade patterns at the U.S. census region level and model trade flows using a standard gravity-like model. Cronovich and Gazel (1998) examine the relative importance of real exchange rates and foreign incomes as determinants of state exports. Coughlin and Pollard (2001) examine the different growth rates of state exports from the late

\footnotetext{
${ }^{3}$ Crandall (1993) reviews the "Rust Belt" phenomenon and the associated job losses.
} 
1980s through the late 1990s and document the importance of competitiveness as opposed to industry mix as the key driver of better performance relative to the national average.

The importance of immigrant links as a source of trade linkages was first explored by Gould (1994). Many subsequent authors have explored the relationship between migration and trade in greater depth. Bandyopadhyay, Coughlin, and Wall (2008) explore the importance of ethnic immigrant networks as drivers of overall exports from U.S. states to a panel of 29 countries. They use data on foreign-born residents in each state from the decennial censuses of 1990 and 2000, and find that the networks only seem to matter for a subset of countries. Herander and Saavedra (2005) use data on the number of immigrants in each state as counted in the 1990 census to explore the importance of immigrant networks for exports from individual states. Peri and Requena-Silvente (2010) conduct a similar study for exports from 50 Spanish provinces to a sample of 77 countries between 1995 and 2008 and find that the importance of immigrants for exports is greatest for differentiated goods and for countries that are culturally distant from Spain.

The synergies between trade finance and international trade are explored in Claessens, Hassib, and van Horen (2015) and Niepmann and Schmidt-Eisenlohr (2015). Claessens, Hassib, and van Horen (2015) examine the importance of internationally active banks as facilitators of international trade through their brick-and-mortar foreign operations. They find that in the period immediately prior to the global financial crisis (1995-2007), the local presence of foreign banks from an importing country is associated with higher exports, especially in sectors that depend the most on trade finance. Niepmann and Schmidt-Eisenlohr (2015) examine the synergies between international finance and international trade from a different perspective, namely that of banks as risk mitigators in international trade.

Cadot, Carrère, and Strauss-Kahn (2011) examine the question of diversification of exports from a sample of 156 countries over a 19-year period, and document the existence of a clear hump-shaped pattern relative to stage of development. They find that export diversification tends to increase with income level (as measured by per capita GDP in purchasing power parity dollars) before a pattern of re-concentration kicks in at an income level of around \$25,000 per capita (in constant 2005 international dollars). Agosin, Alvarez, and Bravo-Ortega (2012) examine the determinants of export diversification over the 1962-2000 period in a sample of 79 countries, and find that more open economies tend to have more diversified exports. Greater levels of human capital tend to be associated with more diversified export patterns, while remoteness tends to be associated with greater specialization.

Apart from the snapshot of specialization in export patterns of individual states in Cassey (2011), there seems to be relatively little work documenting these patterns and how they evolve over time. Our contribution is to document the evolution of specialization over time, differentiating between specialization by destination and specialization by product. We go further by comparing the patterns of specialization in trade with the diversity or otherwise of a state's immigrant population, and ask whether states with more diverse immigrant populations also have more diverse trade patterns. We also provide some evidence on the diversity of a state's international financial linkages, although as already noted and will be explained in detail below, the data we use are imperfect measures of the financial links between individual states and the rest of the world.

(C) Southern Regional Science Association 2017. 


\section{DATA}

We are interested in seeing how diversified the various U.S. states are in terms of their international trade linkages, immigrant linkages, and financial linkages. When it comes to measuring trade linkages, we focus on export links only, as there are no data on imports by individual state. There are relatively good data on the number of immigrants by state from both the decennial census and the American Community Survey (ACS), which we will discuss in more detail below. We are on the shakiest ground when it comes to measuring financial linkages. International financial linkages can take many forms. It would be interesting to know, for example, how internationally diversified investment portfolios are of the residents of each state, or how diversified (by origin) the stock of foreign direct investment in each state is, but the requisite data to measure these dimensions of diversification are not available. We therefore focus on a simple measure of international financial linkages that is derived from data on the presence of foreign banking organizations in each state. See the Appendix for data description and sources.

\subsection{Trade Linkages}

For U.S. states' exports data, we use the Origin of Movement (OM) data compiled by the U.S. Bureau of Census and available from the World Institute for Strategic Economic Research (WISER). These data detail the value of exports from all 50 U.S. states, the District of Columbia, Puerto Rico, and the U.S. Virgin Islands to over 200 foreign destinations. In most cases these destinations are countries, but territories and other claimed land are often included. In these data exports are measured at the port of exit and include the cost of inland freight and insurance. The OM data provide export information by industrial subsectors, classified using the North American Industry Classification System (NAICS) system. Exports data are reported at the three-digit level where industrial subsectors such as "agricultural production" (NAICS 111), "food manufacturing" (NAICS 311), and "merchant wholesalers, nondurable goods" (NAICS 424) are listed. ${ }^{4}$ The OM series contain state exports for 32 subsectors, but excludes exports of services, the production sector that is the largest share of U.S. economy (more than 60 percent of nominal GDP).

The key feature of the state export data is its focus on the location from which exporting begins rather than on the location from which the exported goods are produced. Cassey (2009) gives a complete description of the OM data and also performs tests for data quality. One potential problem is that since the state export data are measured at the port of exit, the origin of movement could be the state in which shipments produced in other states are consolidated. Cassey (2009) argues that this problem is not so widespread as to prevent the use of the OM data in the context of documenting state export patterns.

\subsection{Immigrant Linkages}

States' foreign-born immigrant population data are obtained from the American Community Surveys (ACS) for the period 2005 to 2013 and the decennial census for 1990 and $2000 .^{5}$ The ACS provide annual estimates of foreign-born population by surveying about 3 million households each year, for geographic areas with a population of 65,000 or more.

\footnotetext{
${ }^{4}$ The origin of movement series measures exports from the locations from which firms sell their products which do not always coincide with the locations where export goods are produced. If wholesalers and other intermediaries are active exporters, exports are attributed to their residing states, which may differ from the state where the goods were produced.

${ }^{5}$ ACS and Decennial Census data can be downloaded from the Minnesota Population Center's IPUMS, http://usa.ipums.org/usa
} 
The ACS collects detailed information on the characteristics of the U.S. population and housing. It has the advantage of continuous measurement by producing new data every year rather than every ten years for the decennial census. However, because it is sent to fewer households ( 1 in 100) compared to the decennial census ( 1 in 6 households), ACS counts are subject to a larger margin of error, especially for smaller geographic areas.

Foreign-born population data for 1990 and 2000 are obtained from the decennial census. ${ }^{6}$ These surveys offer estimates of the foreign-born population with detailed demographic, social, and educational and economic characteristics. This provides a comprehensive tool for studying immigrant population at the national and state level.

\subsection{Financial Linkages}

International financial linkages at the individual state level are more challenging to document. We rely on data reported quarterly by the Board of Governors of the Federal Reserve System on U.S. operations of foreign banking entities. These are available quarterly from 1997 and include information on the location of U.S. offices, the type of U.S. office (e.g., whether a representative office with no U.S. assets or a branch with U.S. assets), as well as whether the U.S. office has established an international banking facility.

At the end of the first quarter of 1980, foreign-owned banks and the U.S. branches and agencies of foreign banking organizations had U.S. assets amounting to \$216 billion, or 10.8 percent of all bank assets in the U.S. By the fourth quarter of 2013, this figure had increased to $\$ 3.5$ trillion, or 22.1 percent of U.S. bank assets. Foreign banks' shares of commercial and industrial loans increased over the same period from 14.1 percent to 25 percent of the total outstanding loans in the U.S.

As of the end of 2013, there were 436 foreign banking organizations operating in the U.S., of which 131 were representative offices with no U.S. assets. Unsurprisingly, the state with the most foreign banking operations was New York, with 196, followed by California (67) and Florida (48). A total of 54 different countries had at least one foreign banking organization in the U.S. at the end of 2013, with 48 of these countries having offices in New York. The country with the most bank offices in the U.S. at the end of 2013 was Japan, with 45, followed by Switzerland (42) and Canada (40). In terms of diversity across the U.S., Swiss banks had offices in 18 states, followed by the U.K. (12), and Canada and the Netherlands (11).

\section{MEASURES OF SPECIALIZATION AND DIVERSIFICATION}

Our objective is to see how diversified or specialized U.S. states are in terms of trade, immigration, and financial linkages, and the degree to which that concentration has changed over time. Our dataset comprises information on U.S. state exports, foreign-born population, and total bank deposits for all fifty states, which we use to compute the various measures of diversification.

\footnotetext{
${ }^{6}$ The Census Bureau defines the term foreign born, as "people who are not U.S. citizens at birth." The foreign-born population includes immigrants, legal non-immigrants (e.g., refugees and persons on student or work visas), and persons illegally residing in the U.S.
}

(C) Southern Regional Science Association 2017. 


\subsection{Diversity of Trade Patterns}

We start by documenting patterns of specialization in trade. The detailed data we have on trade patterns allow us to document patterns of specialization and diversification by geographic destination as well as by product.

The Herfindahl-Hirschman index is widely used in the industrial organization literature to measure concentration (Sapir, 1996), and has also been used by others to quantify export diversification (see, for example, Cadot, Carrère, and Strauss-Kahn (2011)). The normalized version of this index is defined as:

$$
H_{s, t}^{\text {Destination }}=\frac{\sum_{c=1}^{C_{S, t}^{X}}\left(\emptyset_{c, s, t}^{X}\right)^{2}-\frac{1}{C_{s, t}^{X}}}{1-\frac{1}{C_{S, t}^{X}}}
$$

where $\emptyset_{c, s, t}^{x}=x_{c, s, t} / \sum_{c=1}^{C_{s, t}^{X}} x_{c, s, t}$, i.e. the exports to country $c$ from state $s$ at date $t\left(x_{c, s, t}\right)$ as a share as a share of the total exports of state $s$ at date $t$, and $C_{s, t}^{X}$ is the number of countries that state $s$ exports to at date $t$. The evolution of the Herfindahl-Hirschman index of export specialization reveals to what extent a region is becoming more specialized or diversified, regardless of how the economic structures of other regions are evolving. A higher index indicates that the region exports to a smaller group of countries and hence is more specialized or less diversified. We will use this index as our baseline measure of specialization or diversification.

Since we also have data on the product composition of each state's exports (see Table 4 in the Appendix), we can compute a second measure of specialization by product as:

$$
H_{s, t}^{\text {Product }}=\frac{\sum_{n=1}^{N_{S, t}^{X}}\left(\phi_{n, s, t}^{x}\right)^{2}-\frac{1}{N_{s, t}^{X}}}{1-\frac{1}{N_{S, t}^{X}}}
$$

where $\emptyset_{n, s, t}^{x}=x_{n, s, t} / \sum_{n=1}^{N_{t}} x_{n, s, t}$, i.e. the exports of product $n$ from state $s$ at date $t\left(x_{n, s, t}\right)$ as a share of the total exports of state $s$ at date $t$, and $N_{s, t}^{X}$ is the number of products that state $s$ exports at date $t$.

Figure 1 shows the Herfindahl-Hirschman indexes by export destination for all fifty states. Perhaps not surprisingly, one of the least diversified states by export destination is Michigan. Most states seem to have relatively diversified export patterns, or, to the extent that they do not, have tended to become more diversified over time. A notable exception is North Dakota, where exports have become more geographically concentrated over time and the state has become the least diversified in the nation, likely due to the recent oil boom in that state. Note that we do not see similar patterns in the other big oil states, Texas and Alaska.

The most diversified states are Florida, Maryland, Louisiana, and Georgia. These states export to a large number of trading partners, and their top five partners account for 30-40 percent of total exports. In contrast, the least diversified states, North Dakota, Maine, South Dakota, and Michigan, have much larger export shares to fewer trading partners. North Dakota sells 79 percent of its exports to Canada, while Maine, South Dakota, and Michigan, respectively, send 55 percent, 45 percent, and 46 percent of their exports to Canada, their largest trading partner. 
The nation's largest states in terms of gross state product have varying degrees of diversification in their export destinations. California ranked 6th in terms of diversification of trading partners, while Texas ranked 37th among the states in 2014. New York and Florida came in 16th and 1st, respectively.

Figure 2 shows the Herfindahl-Hirschman indexes by export product for all fifty states. Note that the patterns of diversification by product differ from the patterns of diversification by destination. ${ }^{7}$ In particular, note that there is less diversification by product than there is by destination. States such as New Mexico, West Virginia, and Vermont stand out as having the least diversified international trade patterns by product, although in all three cases they have become more diversified over time. Texas also stands out in having a relatively diversified (and stable) export pattern by product, contrary to the popular perception that the state depends heavily on oil and energy-related products. States that have diversified their export basket the most since 1997 include New Mexico, Wyoming, and Idaho. On the other hand, Alaska and Washington's exports have become less diversified over time. Indeed, while Washington State exported more than $\$ 90$ billion worth of merchandise in 2014, exports of transportation and equipment (primarily aircraft, engines, and parts assembled by Boeing) accounted for 57 percent of total exports, making its export mix one of the nation's most concentrated.

Vermont, the least diversified (most specialized) state, mainly exports computers and electronic products, which accounted for 69 percent of its total exports in 2014. Exports of chemical manufactures accounts for 57 percent of Wyoming's total exports, while exports of fish and fish products dominate Alaska's exports, at 46 percent of the state's exports. Virginia, Pennsylvania, and North Carolina are the nation's most diversified (least specialized) states. The top five export products make up 56 percent of Virginia and Pennsylvania's total exports and 61 percent of North Carolina's. Virginia's top export product, chemicals, accounts for 16 percent of its total exports, followed by computer and electronic products (13 percent) and transportation equipment (10 percent). Pennsylvania's are chemicals (17 percent), machinery (11 percent), and transportation equipment (10 percent). North Carolina's top exports are chemicals (18 percent), machinery (13 percent), and transportation equipment (13 percent).

The nation's largest states vary in their export concentration. California's top export, computer and electronic products, accounts for 25 percent of its total overseas sales, while Texas's largest export, petroleum and coal products, makes up 21 percent of all goods exports. New York and Florida's chief exports, respectively, account for 33 and 24 percent of their total exports. These largest four states, respectively, ranked $8^{\text {th }}, 18^{\text {th }}, 25^{\text {th }}$, and $13^{\text {th }}$ among states in terms of diversification of export products.

\subsection{Diversity of Immigrant Links}

We next examine the diversity of each state's body of immigrants. As noted above, we use data from the regular decennial census as well as annual data from the ACS. Let $m_{c, s, t}$ denote the number of immigrants from country $c$ in state $s$ at date $t$. Define $\xi_{c, s, t}^{m}=m_{c, s, t} /$ $\sum_{c=1}^{C_{s, t}^{M}} m_{c, s, t}$, i.e. the share of total immigrants in state $s$ at date $t$ that come from country $c$, where $C_{s, t}^{M}$ denotes the number of countries from which immigrants to state $s$ have come at date $t$. We

\footnotetext{
${ }^{7}$ This may partly be due to the highly aggregated nature of the product data we use, specifically just 18 categories at the 3 -digit level.
}

(C) Southern Regional Science Association 2017. 
Figure 1: Diversification of U.S. Exports by Destination Measured by the Herfindahl-Hirschman Index
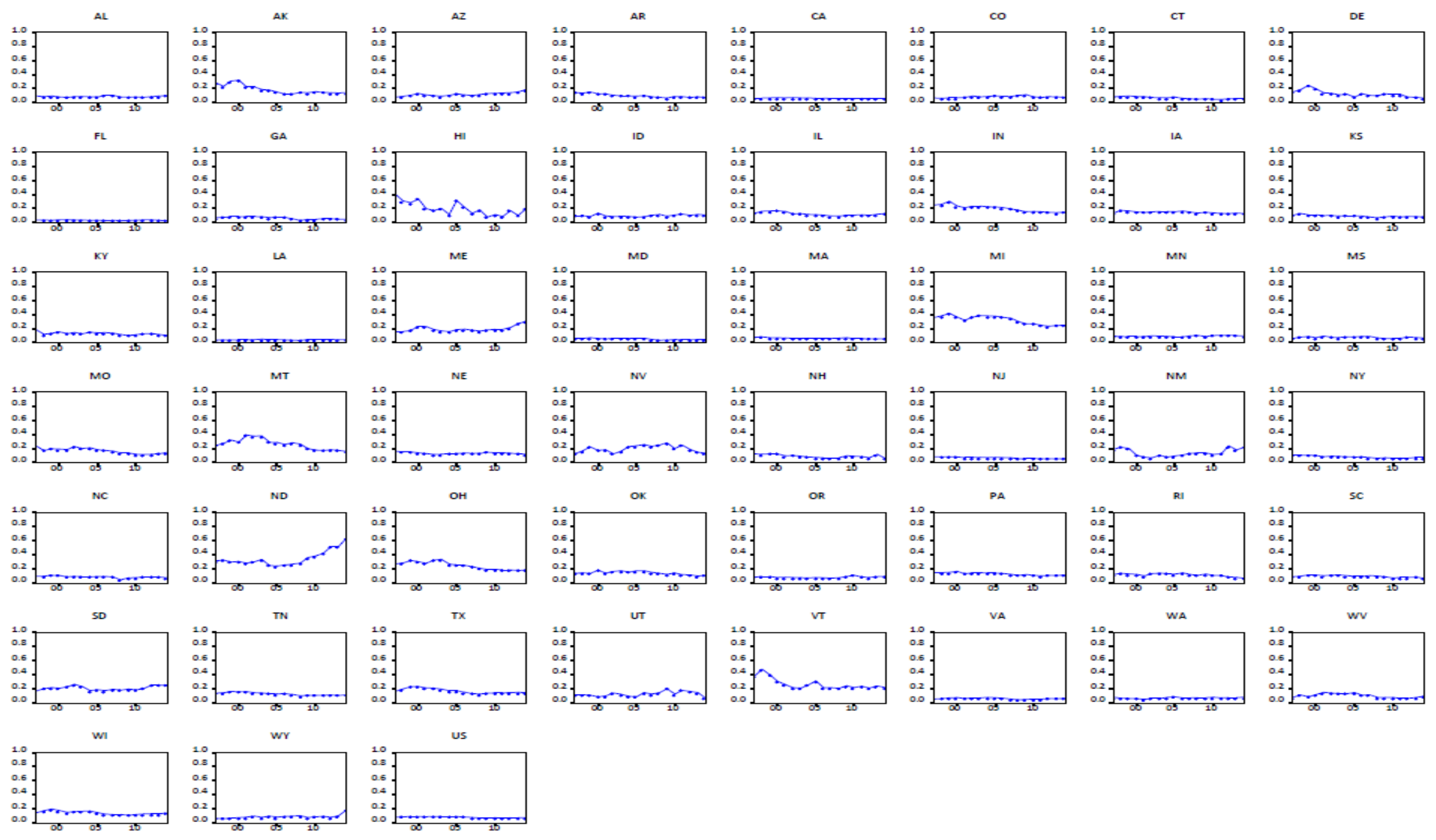

C Southern Regional Science Association 2017. 
Figure 2: Diversification of U.S. Exports by Product Measured by the Herfindahl-Hirschman Index

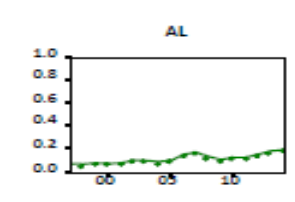

FL

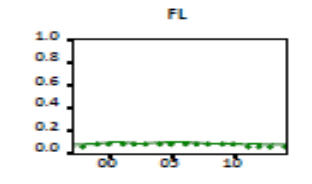

KY

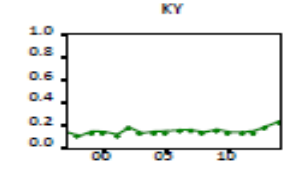

мо

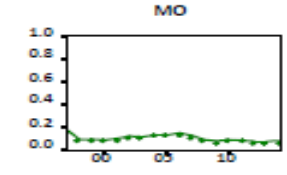

NC
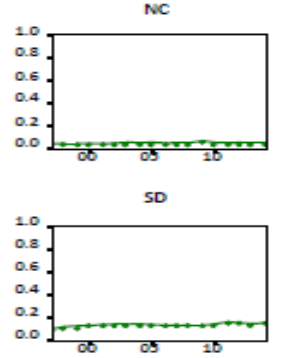

w1

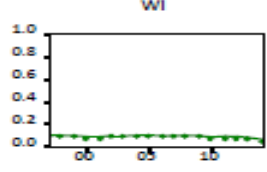

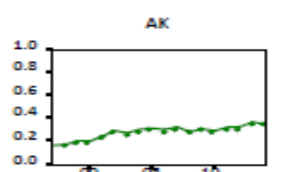
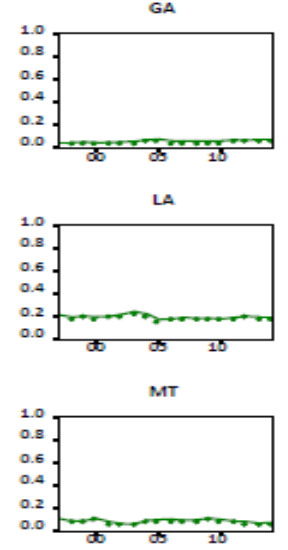

ND

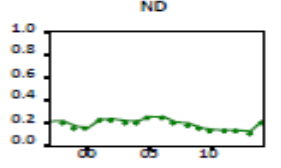

$\mathrm{TN}$
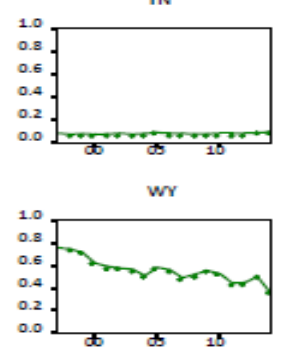
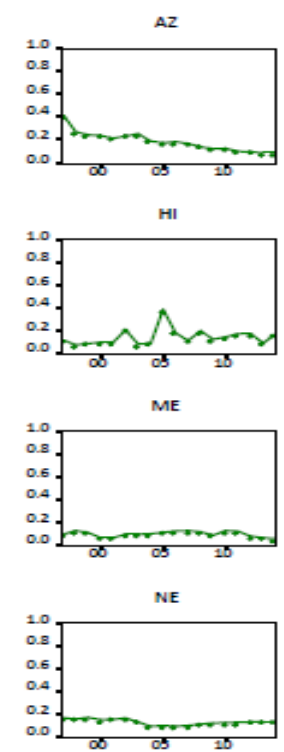

он

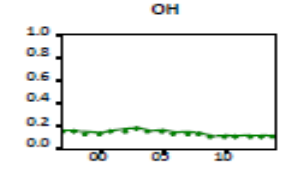

$\mathrm{Tx}$

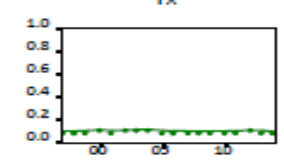

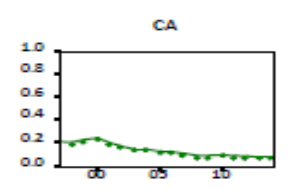
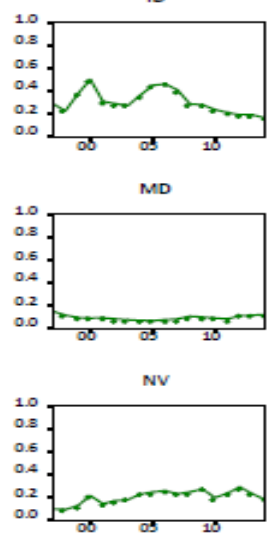

or

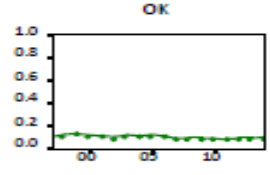

UT
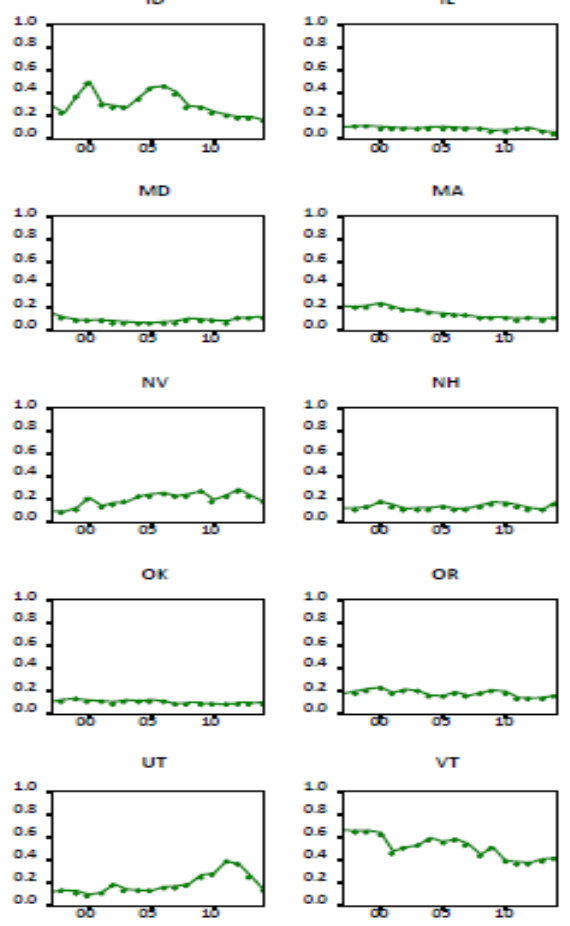

or

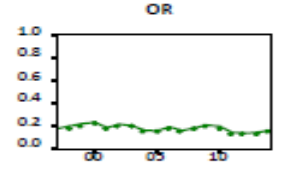

vT

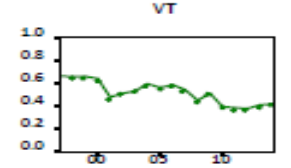

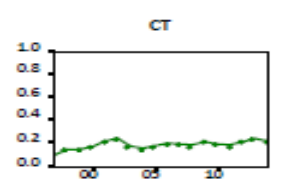
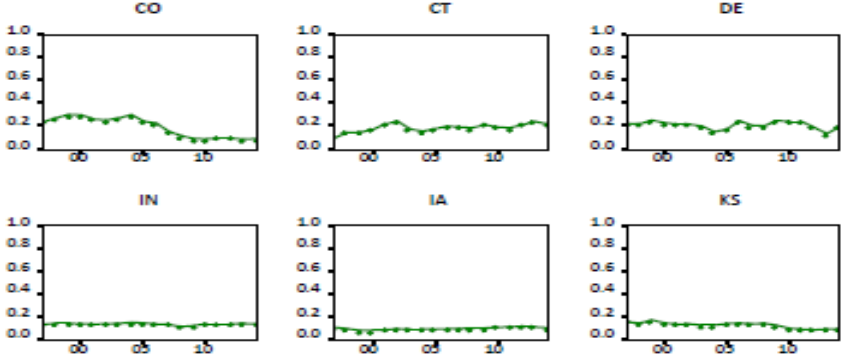

MI

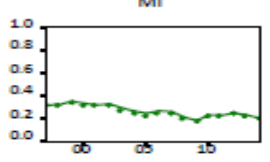

N

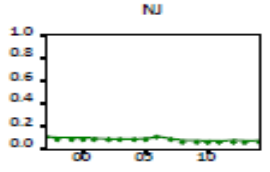

PA

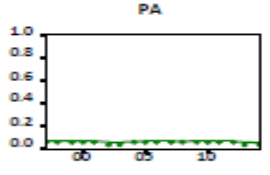

va
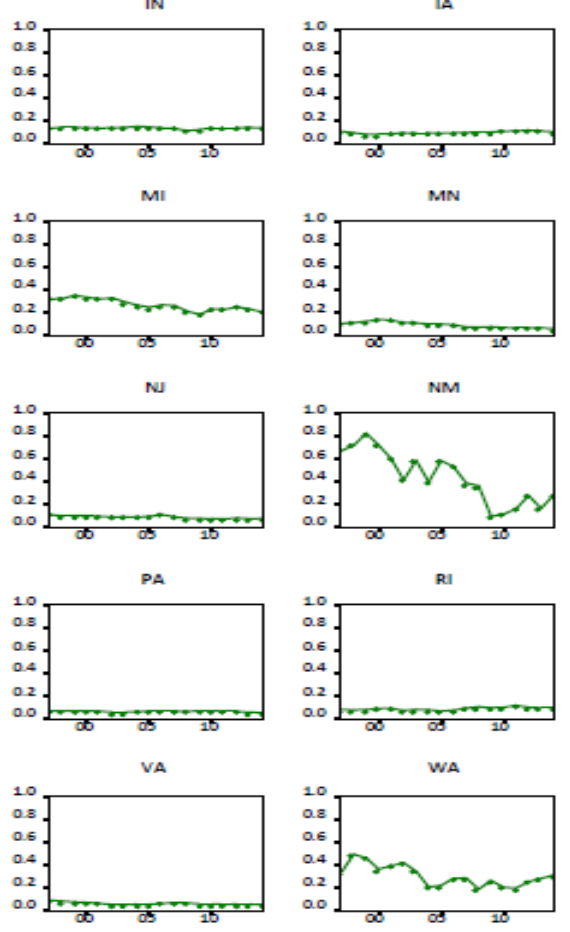

NM

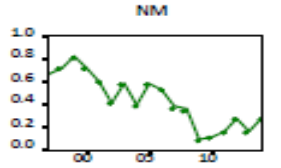

RI

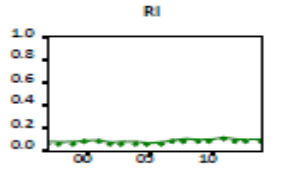

wa

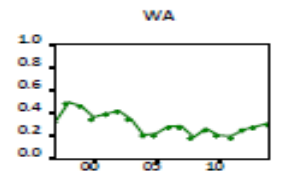

MS

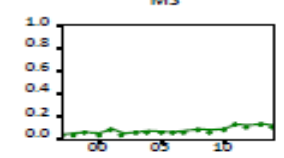

NY

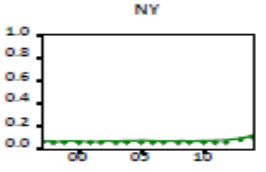

sc

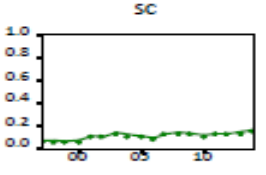

wv

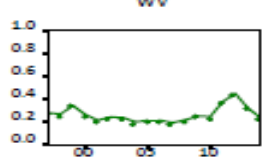


can define a normalized Herfindahl-Hirschman index for the composition state $s$ immigrant body as

$$
H_{s, t}^{\text {Immigrant }}=\frac{\sum_{c=1}^{C_{s, t}^{M}}\left(\xi_{c, s, t}^{m}\right)^{2}-\frac{1}{C_{s, t}^{M}}}{1-\frac{1}{C_{s, t}^{M}}}
$$

when we are looking at concentration by source country.

Figure 3 plots the evolution of the Herfindahl-Hirschman index for each state's immigrant body. We include in the chart the calculated values for 1990 and 2000 using census data so as to provide a slightly longer time series since the ACS data only start in 2005. Again, we see interesting differences in the diversity of state's immigrant groups. For example, Texas, New Mexico, and Arizona have relatively less diverse immigrant groups, perhaps not surprisingly as border states. All three states have relatively high percentages of immigrants from Mexico. Note that this is less true of the fourth state that borders Mexico, California, although it too has a less diverse immigrant body than other big states, like New York or Florida. The extent of immigrant diversity remained relatively the same for most states over the 1990 to 2014 period, with a few exceptions. Arkansas, Colorado, and Utah were more diversified in 2014 compared to 1997, while Maine's immigrant mix became less diversified over that period. Other states, such as Arizona, Colorado, and Nevada exhibit a hump-shaped pattern as the states changed from a more to a less diversified immigrant body.

\subsection{Diversity of Financial Links}

Let $a_{c, s, t}$ denote the U.S. office assets of foreign banking organizations from country $c$ in state $s$ at date $t$. Define $\omega_{c, s, t}^{a}=a_{c, s, t} / \sum_{c=1}^{C_{s, t}^{B}} a_{c, s, t}$, i.e. the share of all foreign bank assets in state $s$ at date $t$ that come from country $c$, where $C_{s, t}^{B}$ denotes the number of countries with foreign banking operations in state $s$ at date $t$. As with trade and immigrant links, we can define a Herfindahl-Hirschman measure of concentration of financial assets as

$$
H_{s, t}^{\text {Finance }}=\frac{\sum_{c=1}^{C_{s, t}^{B}}\left(\omega_{c, s, t}^{a}\right)^{2}-\frac{1}{C_{s, t}^{B}}}{1-\frac{1}{C_{s, t}^{B}}}
$$

when we are looking at concentration by country source of the assets.

Figure 4 plots the evolution of the Herfindahl-Hirschman index for financial linkages. The data here are less representative of actual international financial linkages than the data on trade and migrant stocks are of trade and migration links. Nevertheless, we see some interesting patterns. To begin with, there are lots of states where the index takes a value of 1 . These states have foreign bank assets from just one country and hence their assets are heavily concentrated. In fact, this is true for almost all 50 states, the exceptions being California, Connecticut, Delaware, Florida, Illinois, New York, Texas, and Washington. Not surprisingly, New York has the most diverse representation of foreign banking organizations, with Florida next, followed by California. The diversity of foreign banking operations in Illinois has declined significantly over time. 
Figure 3: Diversification of Immigrants Measured by the Herfindahl-Hirschman Index
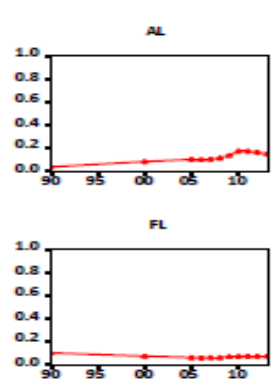

$\kappa$
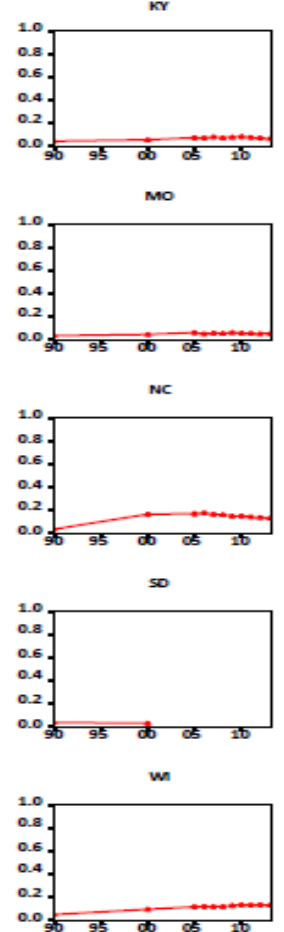
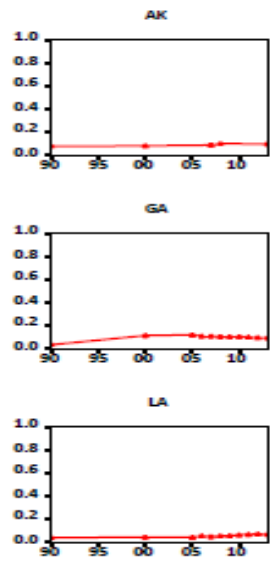

мт

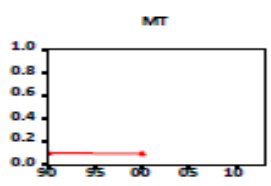

ND
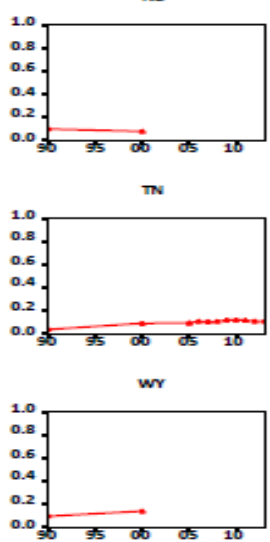
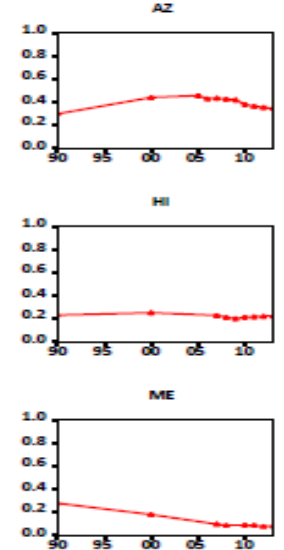

NE

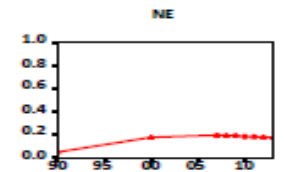

or

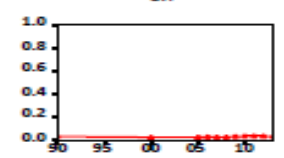

$\mathrm{Tx}$

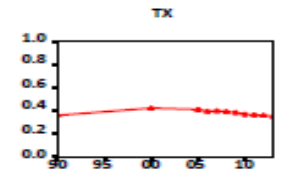

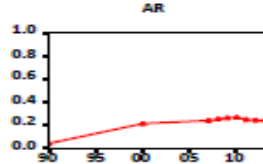

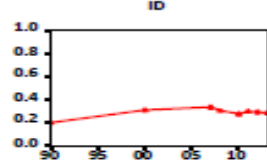

mo

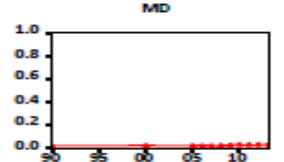

no

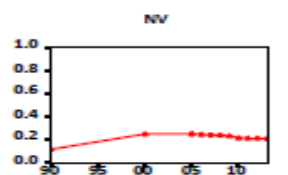

ox

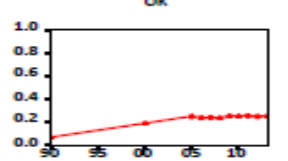

uт

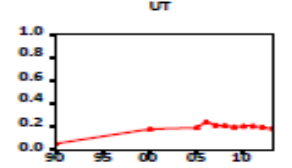

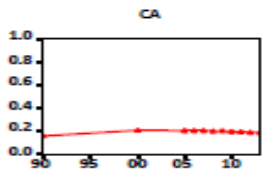

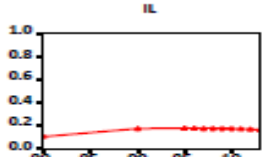

ma

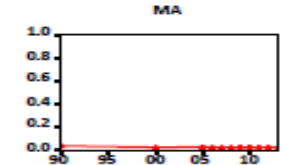

NH

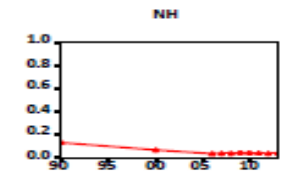

or

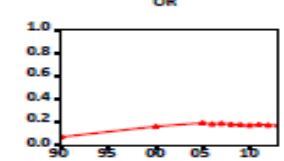

vr

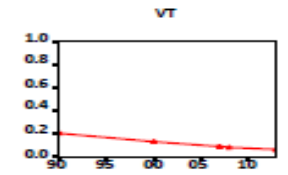

$\infty$
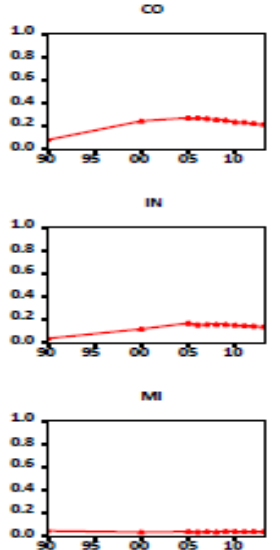

No

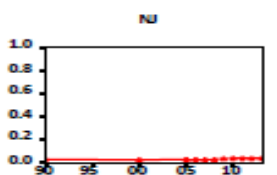

PA

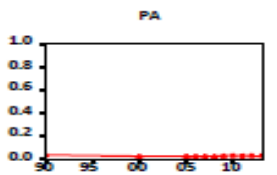

va

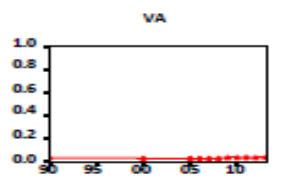

cr
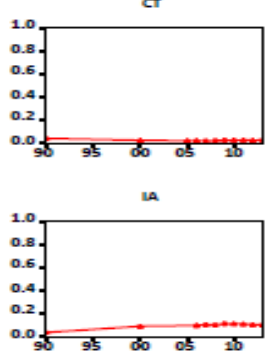

$\mathrm{mn}$

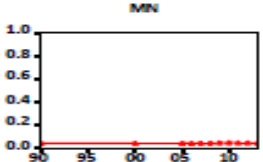

Non

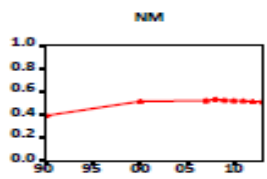

as

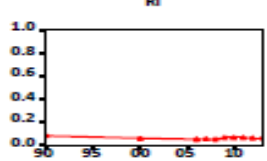

wa

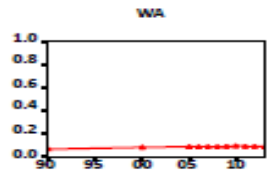

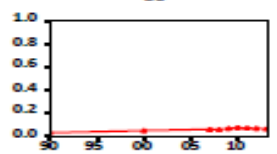
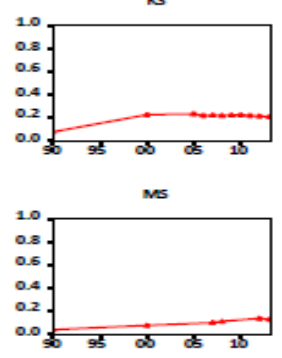

nor
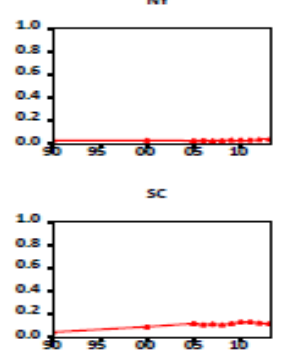

wv

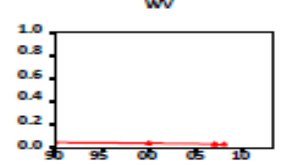

(C) Southern Regional Science Association 2017. 
Figure 4: Diversification of U.S. Foreign Banking Assets Measured by the Herfindahl-Hirschman Index
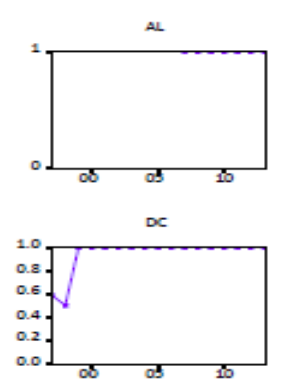

s

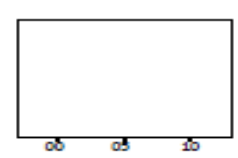

Ms
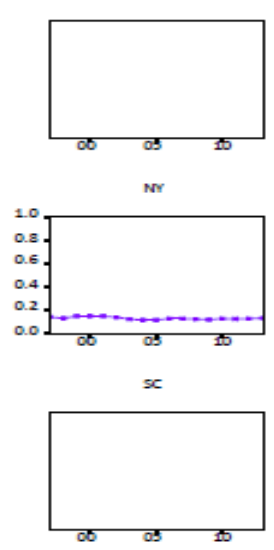

wn

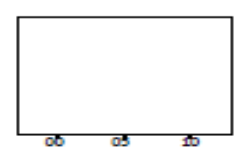

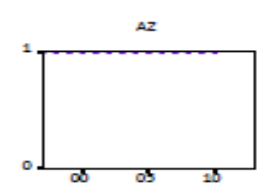
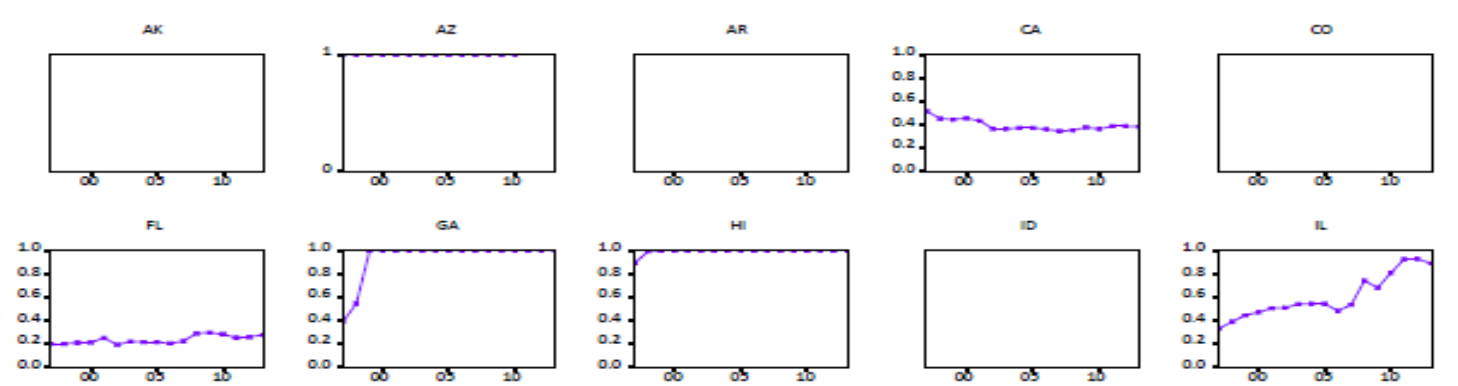

kr
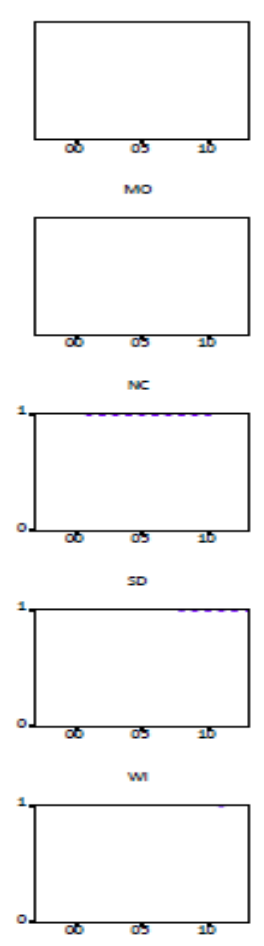

ME
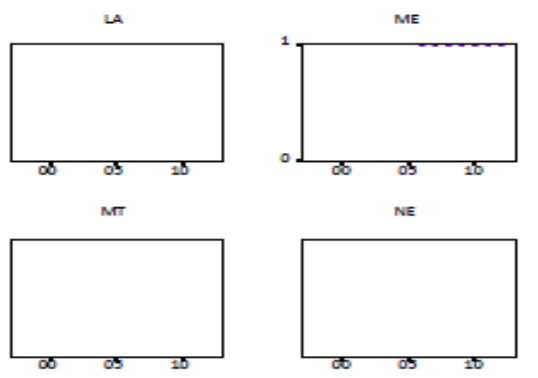

No

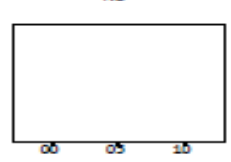

$\mathrm{TN}$

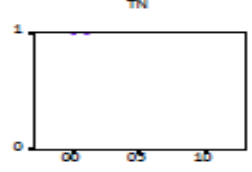

wr
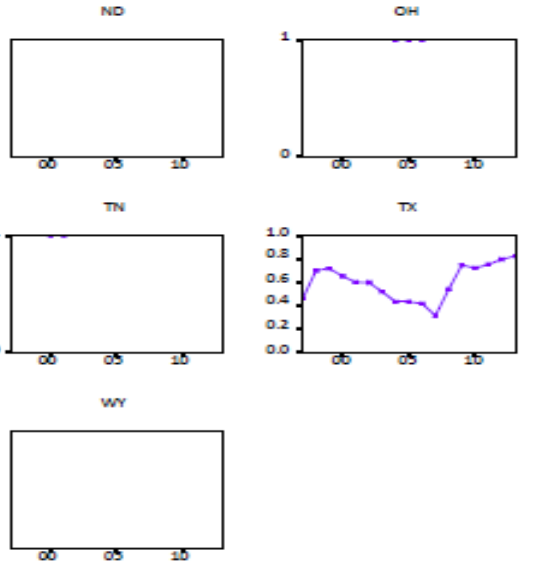
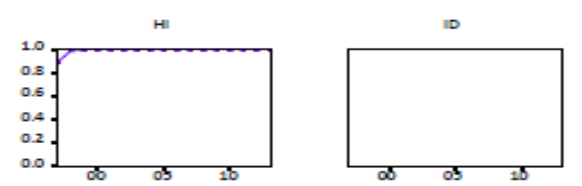

MD
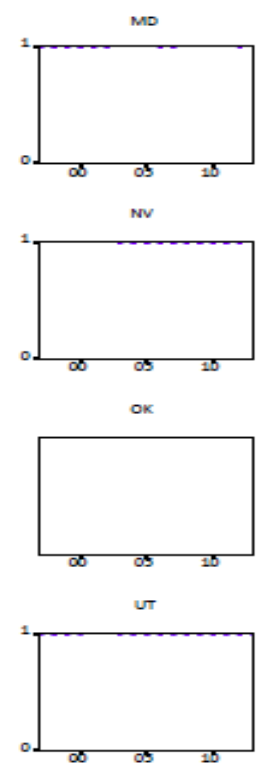
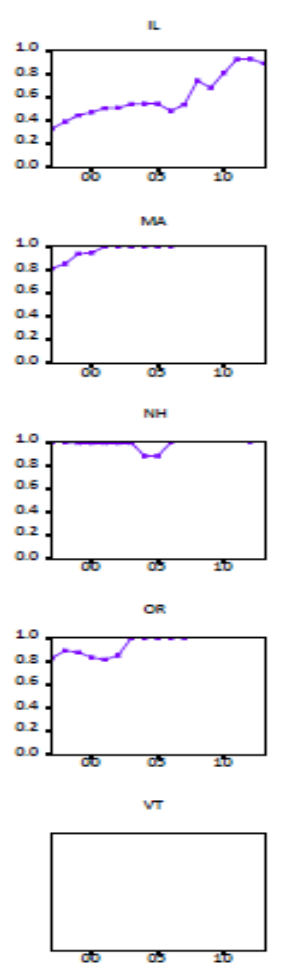
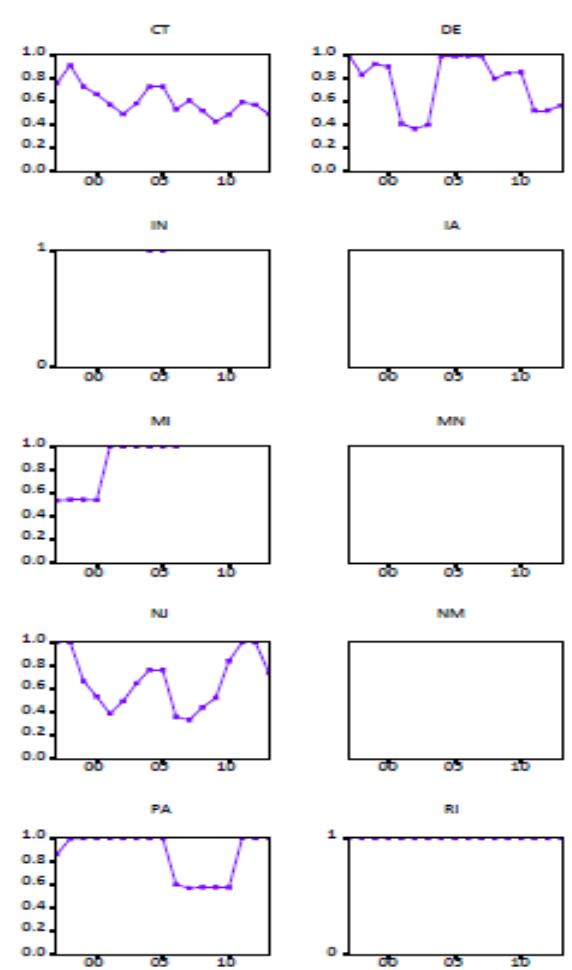

va

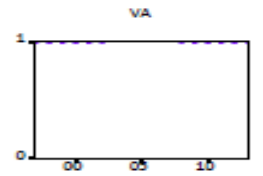

La

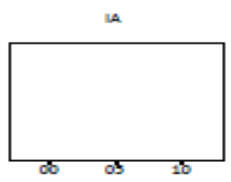

MN

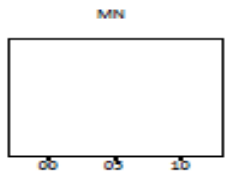

м⿻
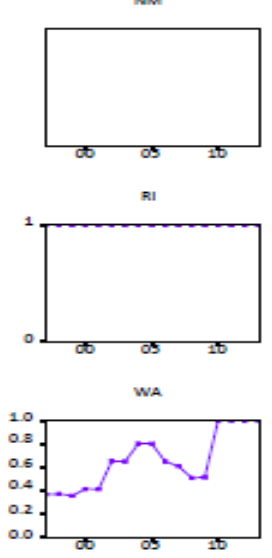

(c) Southern Regional Science Association 2017. 
The Herfindahl-Hirschman measures of U.S. states' diversification are robust to alternative market concentration metrics such as the Theil entropy and Gini indices. The pairwise correlation between Herfindahl-Hirschman index and the Theil and Gini indices confirm that the measures behave similarly and are highly correlated for all measures of economic linkages discussed..$^{8}$

\subsection{Discussion}

It is interesting to consider the three dimensions of globalization in combination for a select number of states that are more keyed into the global economy. Figure 5 plots the evolution of the concentration indexes for six large states. Not surprisingly, New York is highly diversified along all three dimensions of globalization, followed closely by Florida.

How do the various measures of diversification correlate with each other? Do states with more diverse immigrant groups tend to export to a more diverse group of countries, as the results of Gould (1994) might suggest? We calculated the average values of the various HerfindahlHirschman indexes for each state over the sample periods for which they can be computed. Figure 6 presents a series of scatterplots of the various measures against each other. Most of the correlations are fairly weak, but they are positive in all cases. More diversity along one dimension of globalization at the state level is correlated with more diversity along other dimensions of globalization. The strongest pairwise correlation is between the diversity of exports by destination and the diversity of foreign banking assets.

Figure 5: Herfindahl-Hirschman Indexes for the Six Largest U.S. States
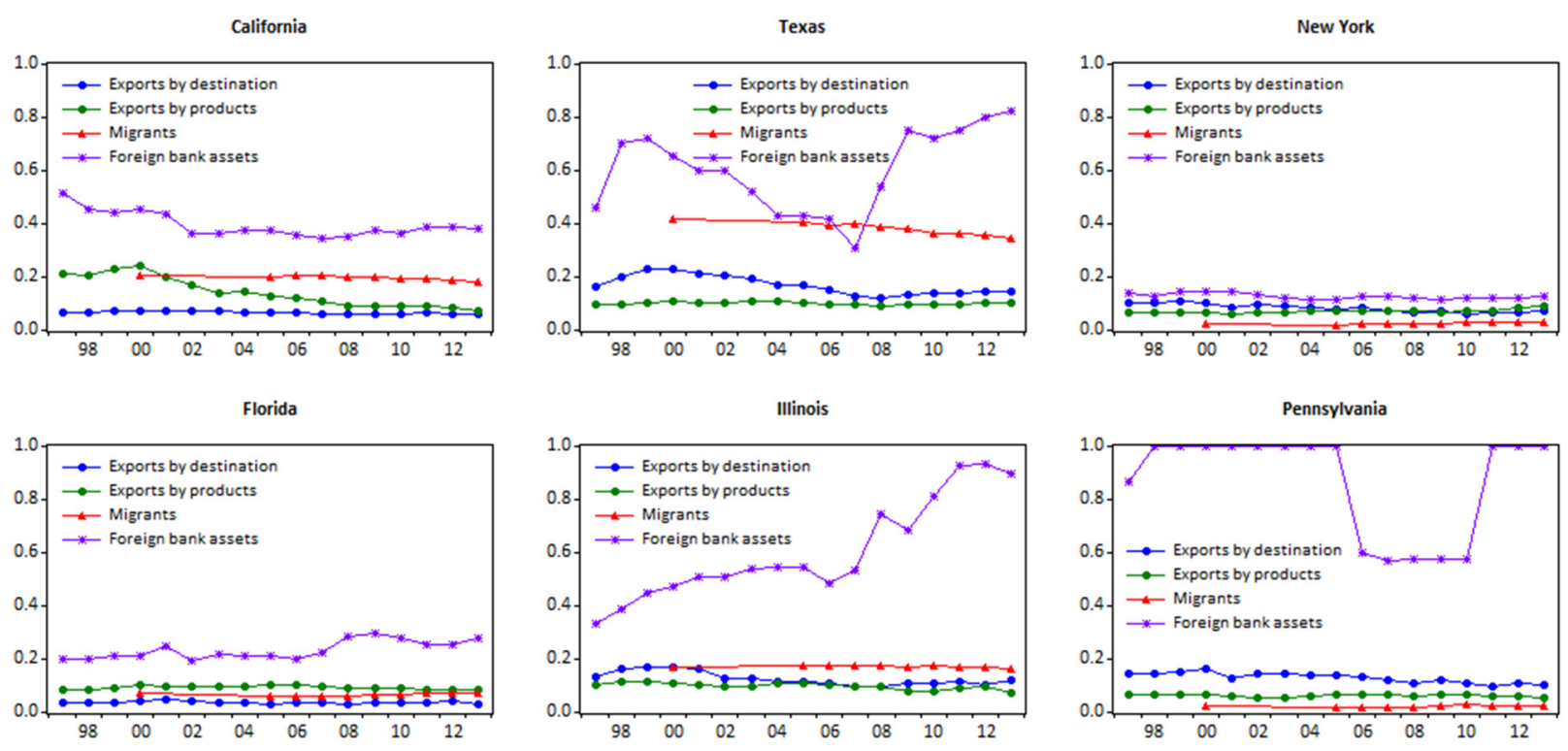

\footnotetext{
${ }^{8}$ Results from the Hirschman-Herfindahl, Theil, and Gini indices show that the levels of economic diversification across states tends to vary across the diversification measure used, but the metrics broadly give consistent results. The pairwise correlations between Hirschman-Herfindahl index and the Theil and Gini indexes show that seven out of eight of the correlations range from 0.75 to 0.97 . The correlation of the Hirschman-Herfindahl and the Gini index for our export-by-destination measure is the lowest at 0.58. Correlations between the Herfindahl and Theil indexes are generally higher across the measures we look at, while the Gini correlations are smaller. Further analysis and details on robustness checks are available upon request.
} 
Finally, we asked whether the diversity of a state's trade pattern might be related to the diversity of the state's economy. Is it easier for a state to export a diverse range of products if it also produces a diverse range of products? Figure 7 suggests that is in fact the case.

\subsection{Determinants of Diversity Across States}

We run a simple panel regression exercise to determine some of the factors that explain the variation in economic diversity based on the existing literature. For instance, Hummels and Klenow (2005) empirically estimate a link between economy size, measured by total income, and the overall degree of specialization. They find that the export of a wider set of goods is the primary avenue for export growth of larger economies. Funke and Ruhwedel (2001) also find the variety of both exports and imports to be positively correlated with per capita income across 19 Organization for Economic Cooperation and Development (OECD) countries. Imbs and Wacziarg (2003) show the existence of a non-linear relationship between income and production diversification; as income per capita rises, production concentration falls and begins to rise after a certain level of income is reached. Klinger and Lederman (2004) and Cadot et al. (2011) find a similar pattern for exports. Gutierrez de Pineres and Ferrantino (1997) analyze the experience of Chile since the mid-1970s and find a positive effect of real exchange rate depreciation and trade reforms on export diversification. Amiti and Venables (2002) suggest that proximity to world markets and presence of other geographical characteristics such as the accessibility of water transport influences the economic structure of a country. Mayda (2010) empirically investigates the determinants of international bilateral migration flows and finds that income opportunities significantly increase migration rates, as do costs of migration. The further away two countries are, the higher the monetary travel costs for the initial move, as well as for visits back home. Therefore, a common land border encourages migration flows, as land travel is often cheaper than air travel. Additionally, network effects play a role in explaining migration rates as documented in Espinosa and Massey (1997). Since immigrants are likely to receive support from other immigrants from the same home country, they will have an incentive to choose destinations with larger communities of fellow citizens.

Based on these findings, we narrow the determinants into five groups:

1. Geography - Does the geographic location of a state explain some of the variability in the indexes? We use dummy variables for states that share a border with Mexico (North border dummy) and with Canada (South border dummy). We also consider the impact of access to the ocean or Great Lakes on the diversity of the various measures of globalization. States that share a border with a foreign country might be expected to have a higher concentration of immigrants from those countries, and states that have a coastal border might export to a broader range of countries than landlocked states. McCallum (1995) found that sharing a border led to increased trade between U.S. states and Canadian provinces.

2. Economic size/income level - We use data on real per capita consumption expenditures to capture the different consumption patterns across states. Do wealthier states differ from states that have less consumption spending with regards to the extent of their diversity? Immigrants might be more attracted to wealthier states as these may have more economic opportunities than poorer states. Indeed, Mayda (2010) and Grogger and Hanson (2011) show that destination income-per capita is a key determinant of migration choices.

(c) Southern Regional Science Association 2017. 
Figure 6: Pairwise Correlations of Different Dimensions of Diversity
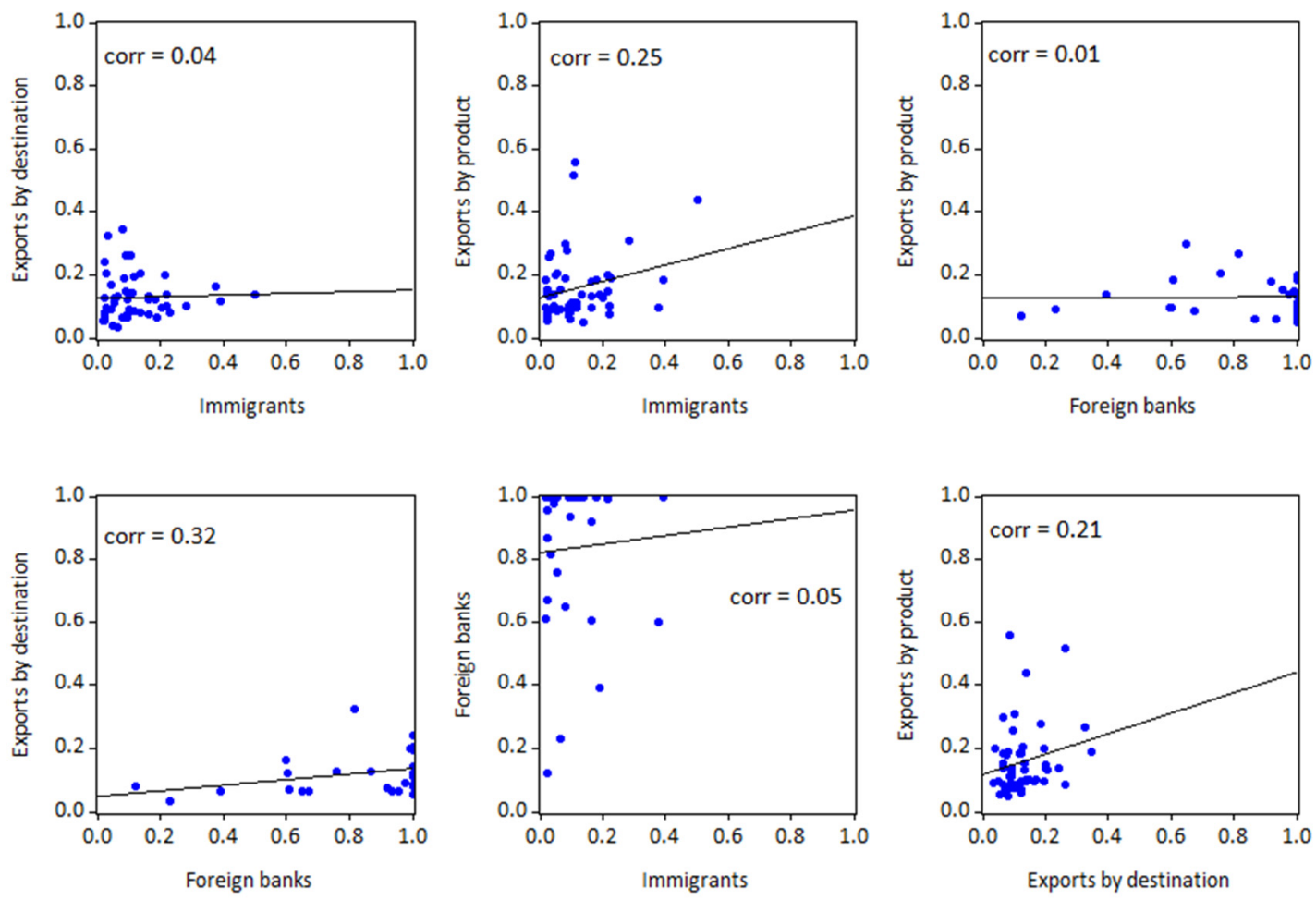

Figure 7: Herfindahl-Hirschman Index: Composition of GSP vs. Exports by Product

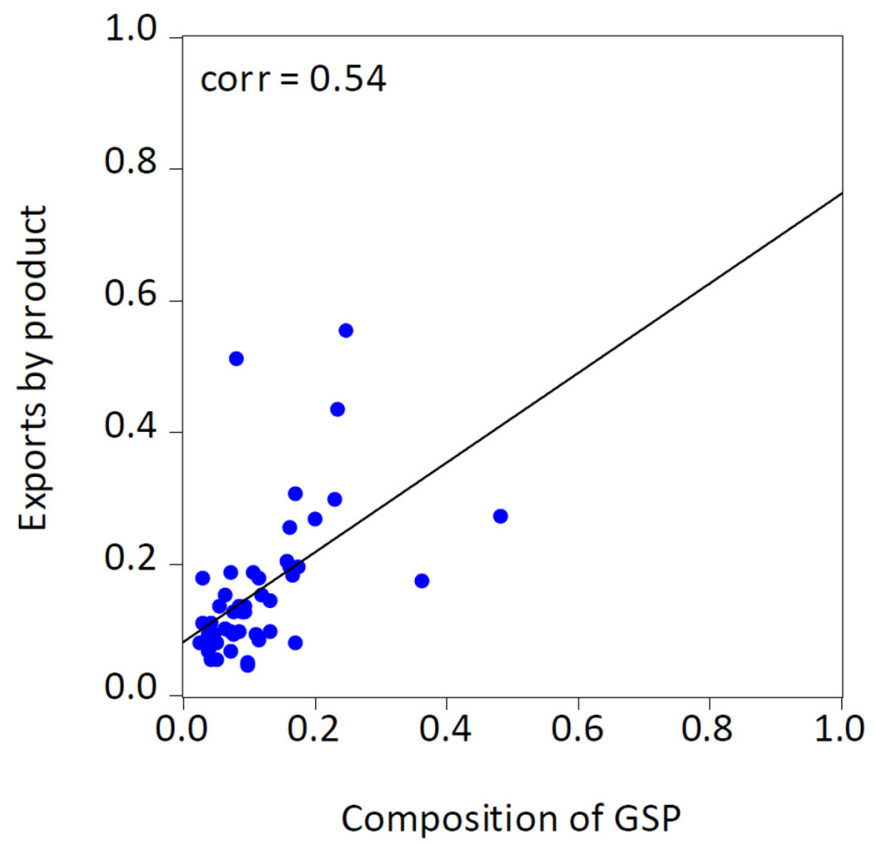

(C) Southern Regional Science Association 2017. 
3. State policies - For this, we use tax burdens imposed on residents by states as a proxy for varying policy stances across states. The data used are per capita state taxes that include both state and local taxes, as reported by the U.S. Tax Foundation. ${ }^{9}$ Do states that pay less in-state taxes attract more foreign banks or immigrants?

4. Economic structure - What does the diversity of a state's production structure mean for the overall diversity of its trade, migration, and financial patterns? We would expect that states that produce a diverse range of products to export a wide range of products.

5. Exposure to foreign countries and cultures - We use data on the amount of personal consumption expenditures U.S. residents spend on foreign travel as a share of total personal expenditures related to services. We also look at travel expenditures in the U.S. by non-U.S. residents. Does exposure to global consumption patterns and cultures explain any variability in the diversity measures we look at? Foreign country travel might establish networks and connections that could promote trade and banking relations between home and foreign countries.

The coefficient of coastal states dummy is negative and statistically significant at the 1 percent level - states that have direct coastal access export to a wider range of countries than landlocked states (Table 1) Exposure to foreign countries and cultures also explains the concentration on export patterns. States whose residents spend more on foreign travel as a share of total expenditures on services have a more diversified export market, lending support to the hypothesis that exposure to foreign markets fosters business relationships and networks that could lower costs of entry into these markets. Surprisingly, however, states that have more expenditure by foreign residents have a more concentrated export market, with a statistically significant coefficient at 1 percent level.

Column 4 shows the estimates of the concentration of exports by product. Four variables prove to be statistically significant in explaining cross-state variations in export basket concentration. States that have coastal access export a wider range of products (i.e. are more diversified) than landlocked states, while states that share a border with either Canada or Mexico have a less diversified export basket. Additionally, and as expected, states that have a more diversified production base and produce a wide range of products, export a more diverse range of products.

Immigrants tend to be concentrated in those states that border the U.S. to the South. States that border Mexico have a much more concentrated immigrant mix, as shown by the magnitude and significance of the regression coefficient ( 0.250 and highly significant at the one percent level). The coefficient for the North dummy, however, is positive and not statistically significant. Sharing a border with Canada does not statistically explain the diversity of states' immigrant population. Nonetheless, states that have a coastal border have a more diverse immigrant mix. Additionally, states that have a diversified economic structure (as measured by the Herfindahl-Hirschman index of states' gross state product), attract a diverse mix of immigrants, as do states where residents spend more on foreign travel. Still, neither the amount of taxes levied by states nor the income levels of residents statistically explains the concentration of migrants' location.

\footnotetext{
${ }^{9} \mathrm{http}: / /$ taxfoundation.org
} 
Finally, the concentration of foreign banking baking assets shown in column 6 is explained by all but two of the variables we look at - those related to the exposure of residents to foreign countries and cultures. ${ }^{10}$ States that share a land or coastal border with a foreign country have a more diversified foreign banking presence. Interestingly, states with a higher tax burden also tend to be more diversified in terms of foreign banking assets. On the other hand, the sign of the regression coefficient on real personal consumption expenditures per capita is positive and statistically significant at the one percent level, implying that wealthier states have a less diversified foreign banking presence. In addition, contrary to our expectation, the exposure of states' residents to foreign countries, as proxied by foreign travel expenditures, does not statistically explain the diversification of states' foreign banking activity.

Table 1: Determinants of Economic Diversification: Regression Results

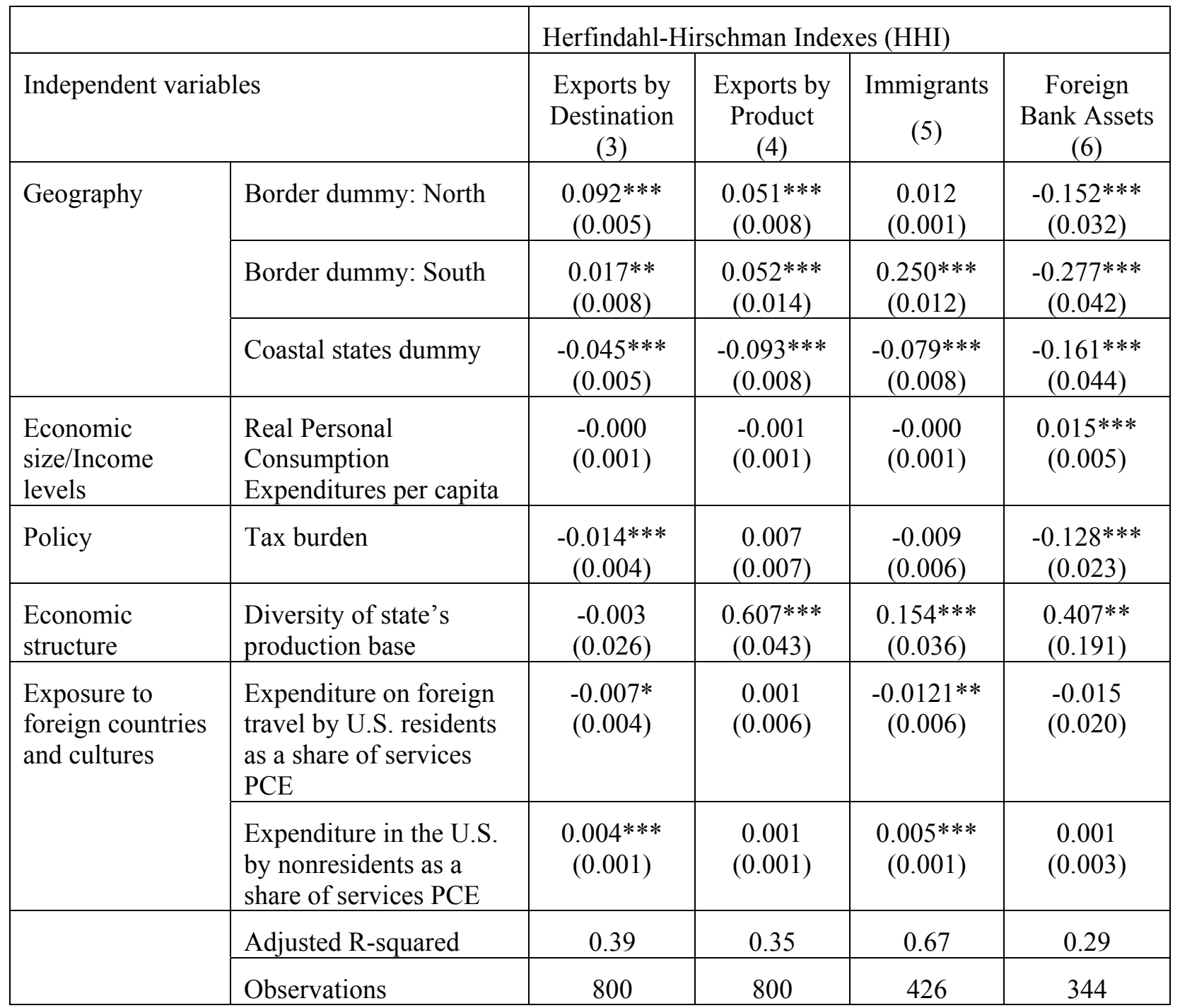

Robust standard errors are in parentheses. ${ }^{* * *} \mathrm{p}<0.01,{ }^{*} \mathrm{p}<0.05,{ }^{*} \mathrm{p}<0.1$. The reduced number of observations in columns (5) and (6) is due, respectively, to the lack of data on foreign-born population by state for the period before 2005, and the limited number of states with foreign bank assets. See Table 5 in the Appendix for the summary statistics of each regression variable.

\footnotetext{
${ }^{10}$ Regression results of foreign banking assets should be interpreted with caution because of the limited foreign financial and banking data available at the state-level.
}

(C) Southern Regional Science Association 2017. 
Overall, however, geography and network effects play the dominant roles in explaining cross-state diversity patterns. Exposure to foreign countries and cultures influences the location of immigrants and the destination of exports, while geography explains diversity of all four measures of globalization considered.

\subsection{Diversity Relative to the United States}

U.S. policy as regards foreign trade, immigration, and cross-border banking is set at the federal rather than the state and local level. In principle, it is as easy for a company in New York to export as it is for a company in Kansas. Likewise, it is as easy for an immigrant from India to settle in Florida as it is for that same immigrant to settle in California. A foreign banking organization seeking to set up shop should find it as easy to do so in Texas as in New York. Of course, other factors matter, starting with geography in the case of trade. Immigrants find it more attractive to be with others from their home country. Financial organizations typically set up shop where there are already a large number of other financial organizations to take advantage of established networks such as access to a specialized labor pool and support services.

We can construct some simple measures of how specialized states are by simply comparing how many countries a state exports as a share of the set to which the nation exports. That is, we define:

$$
D_{s, t}^{X}=\frac{C_{S, t}^{X}}{C_{U S, t}^{X}}
$$

where $C_{S, t}^{X}$ is the number of countries that state $s$ exports to at date $t$, and $C_{U S, t}^{X}$ is the number of countries that the U.S. as a whole exports to at date $t$.

A similar measure can be constructed for immigration:

$$
D_{S, t}^{M}=\frac{C_{S, t}^{M}}{C_{U S, t}^{M}}
$$

where $C_{\mathrm{US}, t}^{M}$ is the number of countries from which immigrants to the U.S. have come from at date $t$.

Alternatively, we explore the similarity of states' exports relative to the nation's. Using an export similarity index proposed by Finger and Kreinin (1979), we calculate a measure of the similarity between the sectoral and geographic concentration of states' exports to that of the nation. The index is based on the export shares of each product or destination in each state's total exports relative to the national share. For each product and destination, the minimum between the state product or destination share and national share is computed. These minimum shares are summed across all products or destinations each state exports and the sum is multiplied by 100 . This index is defined as:

$$
\operatorname{ESI}(s u s, w)=100 * \sum_{j} \min \left[\frac{X_{j(s, w)}}{\sum_{j} X_{j(s, w)}}, \frac{X_{j(U S, w)}}{\sum_{j} X_{j(U S, w)}}\right]
$$

where $\operatorname{ESI}(s u s, w)$ refers to the export similarity index of state $s$ and overall $U S$ to the world $w$, $X_{j(s, w)}$ refers to the exports of product $j$ from state $s$ to the world and similarity $X_{j(U S, w)}$ refers to exports of product $j$ from the $U S$ to the world. $\sum_{j} X_{j(s, w)}$ and $\sum_{j} X_{j(U S, w)}$ are total exports of state $s$ and $U S$ to world $w$, respectively. This index ranges from zero, indicating complete 
dissimilarity, to 100, indicating the state's product and destination distribution of exports is identical to the national distribution, and the state and nation are perfect competitors. An index value close to 100 can be interpreted that the two regions are competitors in the common market. The same index is computed based on export destination.

Table 2 shows a wide range of export similarities by product with values for 2014 ranging from 26.1 for Alaska, which indicates little similarity with the national distribution, to levels exceeding 80.0 for Illinois, Florida, and Virginia. The table also shows how the index changed during the 1997-2014 period. The export similarity index increased for 28 of the 50 states, indicating that the product distribution of exports from these states became more similar to the national distribution. On the other hand, 22 states experienced declines over this period, indicating their exports became more differentiated from the national distribution. New York had the largest decline of 16.9 points.

The importance of specific export destinations has also changed over time and varies across states. Table 3 shows export similarities by geographic destinations of state exports. The 2014 index varies from 40.6 for Hawaii to 84.7 for Tennessee. Nine other states had index values exceeding 80, indicating close similarity of these states' geographic distribution to the national distribution. The table also shows how the geographic concentration of each state's exports has changed during the 1997-2014 period. A total of 34 states experienced an increase in the index during this period, while 16 states saw a decrease. The largest decrease was in Connecticut.

We also looked at a somewhat simpler measure of the diversity of a state's international banking relationships, one defined as the number of different countries that have a banking presence in the state as a share of the total number of countries with a banking presence in any U.S. state. ${ }^{11}$ As before, let $C_{s, t}^{B}$ denote the number of countries with foreign banking organizations in state $s$ at date $t$, and $C_{U S, t}^{B}$ denote the number of countries with foreign banking operations anywhere in the U.S. at date $t$. Our basic measure of international banking diversity at the state level is defined as:

$$
D_{s, t}^{B}=\frac{C_{s, t}^{B}}{C_{U S, t}^{B}}
$$

For example, at the end of 2013 foreign banking organizations from nine countries had offices in Texas, out of a total representation across all U.S. states of 54 countries. By contrast, foreign banking organizations from 48 of the 54 countries represented had offices in New York.

Figure 8 shows how these measures evolve across states. By construction, this measure is smoother than the Herfindahl-Hirschman index, but it shows essentially the same patterns. Focusing just on New York, we see that almost every bank that has an office in the U.S. has an office in New York. About 40 percent of the foreign banks that have offices in the U.S. have offices in California and Florida, while about 20 percent have offices in Texas and Illinois. No other states register as highly in terms of foreign bank representation.

\footnotetext{
${ }^{11}$ We could do a similar calculation with the trade and migration data, although in reality most states have trade relationships with most countries in the world, and all states host immigrants from most countries around the world. Financial relationships are much more concentrated.
}

(C) Southern Regional Science Association 2017. 
Table 2. Export Similarity Index by Export Product

\begin{tabular}{|c|c|c|c|}
\hline State & 1997 & 2014 & Difference between 1997 and 2014 \\
\hline Alabama & 69.8 & 61.5 & -8.3 \\
\hline Alaska & 18.4 & 21.6 & 3.2 \\
\hline Arizona & 57.0 & 71.5 & 14.5 \\
\hline Arkansas & 63.8 & 71.7 & 7.8 \\
\hline California & 73.6 & 76.3 & 2.7 \\
\hline Colorado & 62.3 & 68.0 & 5.7 \\
\hline Connecticut & 74.9 & 65.1 & -9.7 \\
\hline Delaware & 52.3 & 64.7 & 12.5 \\
\hline Florida & 83.9 & 83.0 & -0.9 \\
\hline Georgia & 76.0 & 72.1 & -3.9 \\
\hline Hawaii & 42.6 & 54.9 & 12.4 \\
\hline Idaho & 47.4 & 52.0 & 4.6 \\
\hline Illinois & 82.3 & 83.1 & 0.8 \\
\hline Indiana & 70.5 & 70.4 & -0.1 \\
\hline Iowa & 59.0 & 58.4 & -0.5 \\
\hline Kansas & 56.3 & 66.1 & 9.7 \\
\hline Kentucky & 70.0 & 62.8 & -7.2 \\
\hline Louisiana & 32.0 & 41.5 & 9.5 \\
\hline Maine & 50.8 & 47.7 & -3.1 \\
\hline Maryland & 72.4 & 78.2 & 5.8 \\
\hline Massachusetts & 69.0 & 65.7 & -3.3 \\
\hline Michigan & 56.5 & 64.7 & 8.2 \\
\hline Minnesota & 72.5 & 72.3 & -0.2 \\
\hline Mississippi & 56.2 & 64.6 & 8.4 \\
\hline Missouri & 68.0 & 72.2 & 4.2 \\
\hline Montana & 45.7 & 58.1 & 12.3 \\
\hline Nebraska & 54.1 & 51.1 & -3.0 \\
\hline Nevada & 54.4 & 45.3 & -9.1 \\
\hline New Hampshire & 66.5 & 54.8 & -11.7 \\
\hline New Jersey & 70.0 & 73.6 & 3.6 \\
\hline New Mexico & 38.7 & 51.1 & 12.3 \\
\hline New York & 74.3 & 57.4 & -16.9 \\
\hline North Carolina & 71.6 & 75.0 & 3.4 \\
\hline North Dakota & 39.7 & 40.5 & 0.8 \\
\hline Ohio & 68.8 & 73.7 & 4.9 \\
\hline Oklahoma & 76.0 & 65.2 & -10.8 \\
\hline Oregon & 59.8 & 60.5 & 0.7 \\
\hline Pennsylvania & 78.0 & 76.8 & -1.1 \\
\hline Rhode Island & 66.7 & 53.6 & -13.1 \\
\hline South Carolina & 63.9 & 61.7 & -2.2 \\
\hline South Dakota & 65.8 & 53.7 & -12.1 \\
\hline Tennessee & 76.3 & 78.4 & 2.1 \\
\hline Texas & 82.2 & 73.0 & -9.2 \\
\hline Utah & 62.2 & 58.2 & -3.9 \\
\hline Vermont & 37.0 & 42.7 & 5.6 \\
\hline Virginia & 64.2 & 80.8 & 16.6 \\
\hline Washington & 47.2 & 49.1 & 1.8 \\
\hline West Virginia & 26.0 & 45.9 & 19.9 \\
\hline Wisconsin & 74.3 & 67.3 & -7.0 \\
\hline Wyoming & 18.2 & 33.9 & 15.7 \\
\hline
\end{tabular}

(C) Southern Regional Science Association 2017. 


\section{Table 3: Export Similarity Index by Export Destination}

\begin{tabular}{|c|c|c|c|}
\hline State & 1997 & 2014 & Difference between 1997 and 2014 \\
\hline Alabama & 83.1 & 77.7 & -5.4 \\
\hline Alaska & 35.5 & 51.9 & 16.4 \\
\hline Arizona & 61.2 & 65.7 & 4.5 \\
\hline Arkansas & 76.5 & 78.2 & 1.7 \\
\hline California & 74.6 & 80.0 & 5.4 \\
\hline Colorado & 72.7 & 83.7 & 10.9 \\
\hline Connecticut & 76.1 & 65.3 & -10.8 \\
\hline Delaware & 67.0 & 59.9 & -7.2 \\
\hline Florida & 50.1 & 54.6 & 4.5 \\
\hline Georgia & 82.2 & 83.2 & 1.0 \\
\hline Hawaii & 32.7 & 40.9 & 8.2 \\
\hline Idaho & 64.0 & 63.3 & -0.8 \\
\hline Illinois & 79.4 & 79.8 & 0.4 \\
\hline Indiana & 69.0 & 76.5 & 7.5 \\
\hline Iowa & 73.0 & 78.7 & 5.7 \\
\hline Kansas & 79.0 & 83.4 & 4.4 \\
\hline Kentucky & 70.2 & 73.4 & 3.2 \\
\hline Louisiana & 60.5 & 63.9 & 3.4 \\
\hline Maine & 61.8 & 58.7 & -3.1 \\
\hline Maryland & 70.1 & 71.2 & 1.1 \\
\hline Massachusetts & 76.7 & 73.9 & -2.8 \\
\hline Michigan & 54.6 & 68.5 & 13.9 \\
\hline Minnesota & 76.0 & 79.4 & 3.3 \\
\hline Mississippi & 72.6 & 68.4 & -4.2 \\
\hline Missouri & 68.5 & 80.3 & 11.8 \\
\hline Montana & 57.1 & 65.4 & 8.3 \\
\hline Nebraska & 71.7 & 77.2 & 5.4 \\
\hline Nevada & 60.7 & 62.1 & 1.4 \\
\hline New Hampshire & 71.1 & 75.9 & 4.8 \\
\hline New Jersey & 79.4 & 80.3 & 0.8 \\
\hline New Mexico & 32.2 & 46.2 & 14.0 \\
\hline New York & 74.5 & 68.1 & -6.3 \\
\hline North Carolina & 81.5 & 82.5 & 1.1 \\
\hline North Dakota & 52.0 & 41.9 & -10.2 \\
\hline Ohio & 66.4 & 76.4 & 10.0 \\
\hline Oklahoma & 72.3 & 75.3 & 3.0 \\
\hline Oregon & 62.6 & 58.0 & -4.5 \\
\hline Pennsylvania & 78.3 & 80.5 & 2.2 \\
\hline Rhode Island & 74.8 & 71.1 & -3.6 \\
\hline South Carolina & 75.8 & 69.9 & -5.8 \\
\hline South Dakota & 65.1 & 63.7 & -1.4 \\
\hline Tennessee & 81.0 & 84.7 & 3.8 \\
\hline Texas & 64.2 & 68.5 & 4.3 \\
\hline Utah & 64.5 & 64.2 & -0.4 \\
\hline Vermont & 47.6 & 60.8 & 13.2 \\
\hline Virginia & 68.6 & 80.3 & 11.7 \\
\hline Washington & 56.6 & 58.5 & 1.9 \\
\hline West Virginia & 69.2 & 65.5 & -3.7 \\
\hline Wisconsin & 75.6 & 80.2 & 4.6 \\
\hline Wyoming & 62.1 & 57.7 & -4.4 \\
\hline
\end{tabular}

(C) Southern Regional Science Association 2017. 
Figure 8: Countries Represented in Each State as a Share of Total Countries Represented in the Nation
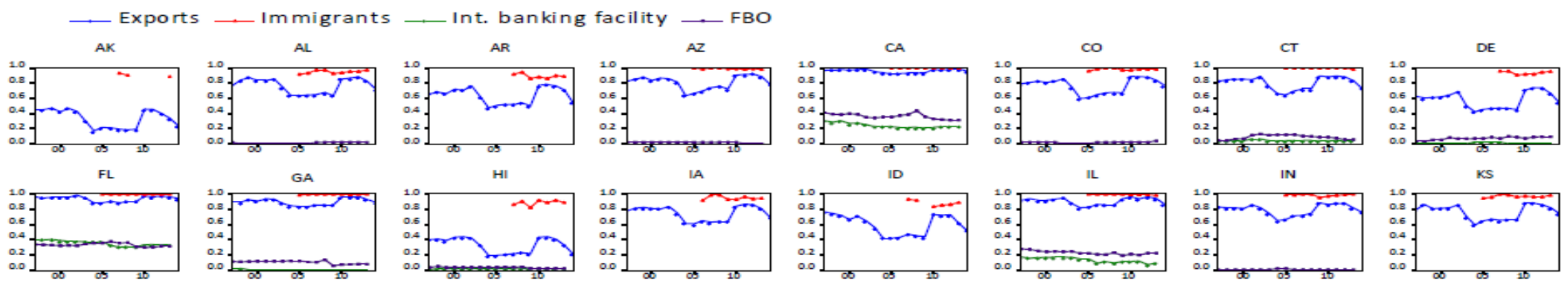

GA

IA
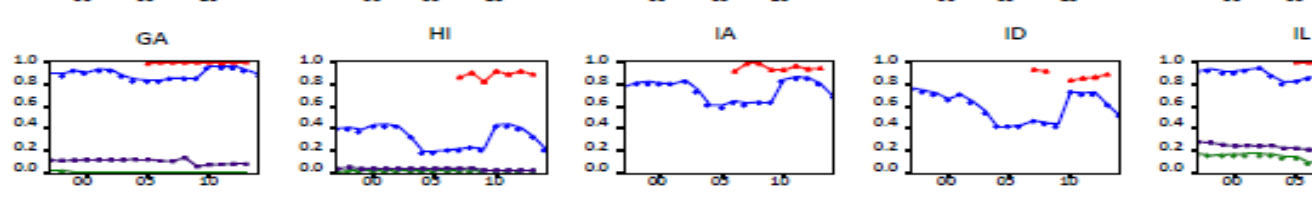

MA

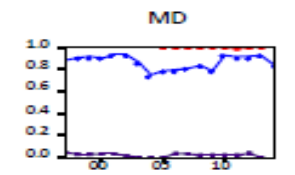

ME
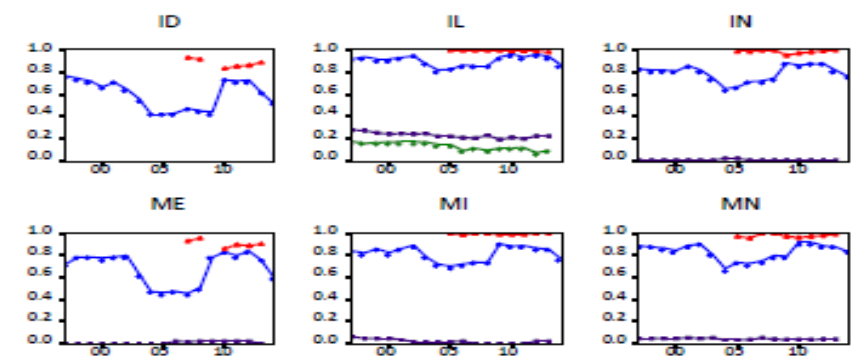

NE

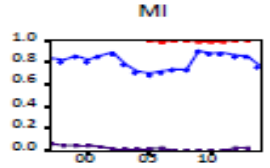

$\mathrm{MN}$

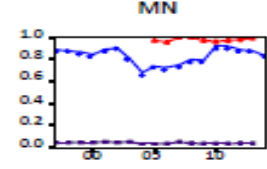

$\mathrm{NH}$

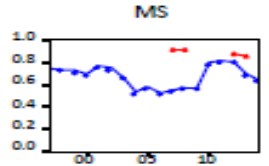

MT

NC
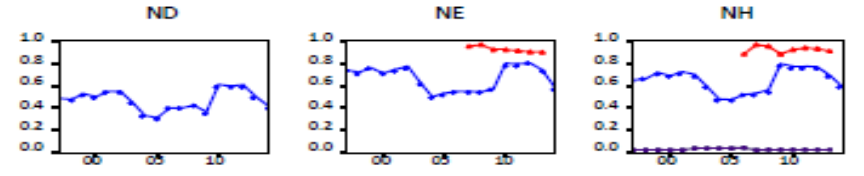

OR

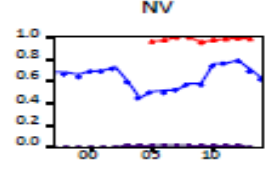

$\mathrm{OH}$
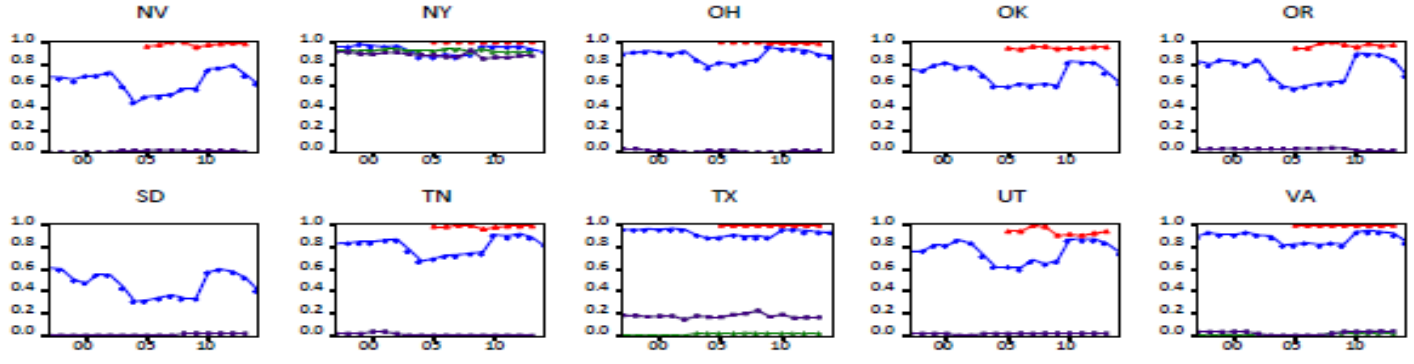

VA

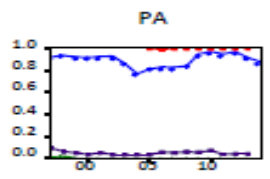

$\mathrm{N}$

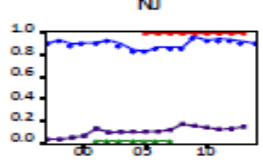

RI

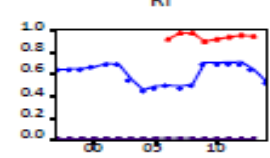

vT
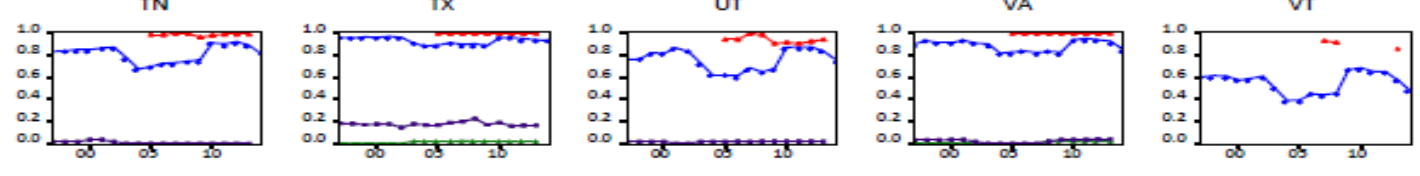

WA
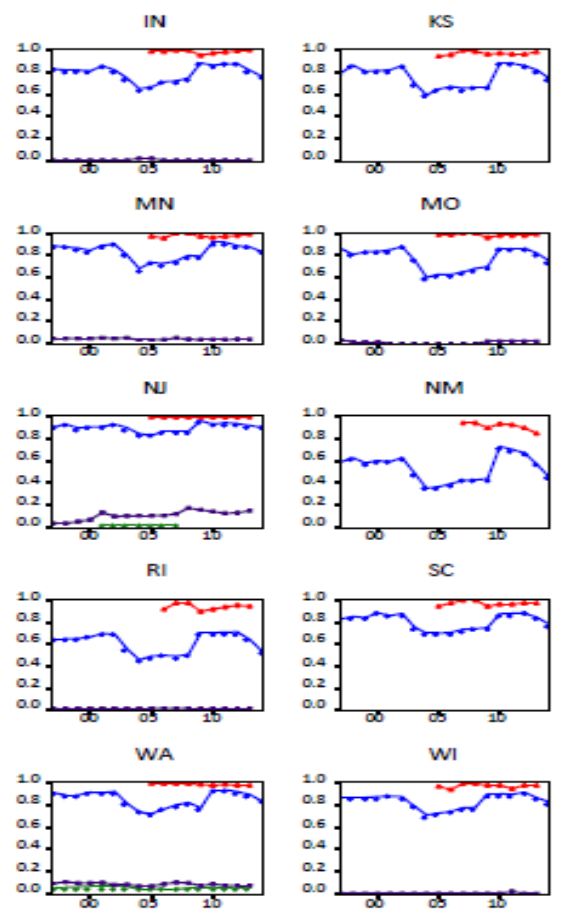

мо

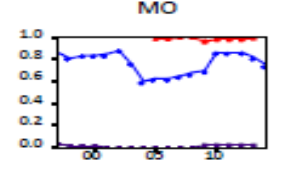

NM

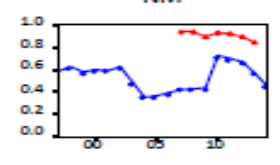

$\mathrm{SC}$

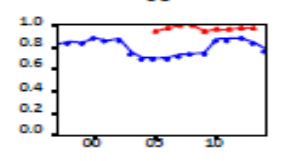

WI
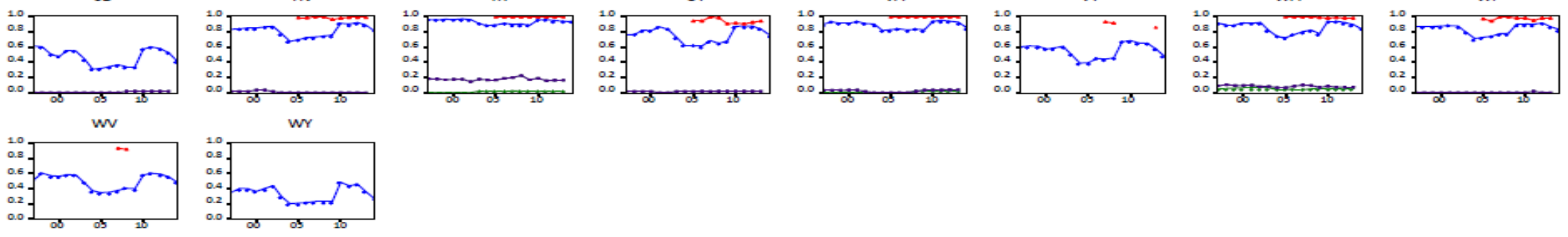

(C) Southern Regional Science Association 2017. 
We also looked at just those foreign banking organizations in the U.S. that had established an international banking facility. For example, three Swiss banks had a total of 40 offices across the U.S. at the end of 2013, but only seven of those offices had an international banking facility, with three of these being in New York, two in California, and one each in Florida and Connecticut. We construct our second measure of financial diversification by computing the number of countries with which an individual state has an international banking facility as a share of the total number of countries with which there are foreign banking facilities. There were 45 countries with an international banking facility anywhere in the U.S. in 2013 down from 53 in 1997. New York had banking facilities set up by 41 of the 45 countries in 2013, while Florida, California, and Illinois respectively had foreign banking facilities by 15, 10 and 4 different countries.

\section{CONCLUSIONS}

This paper documents patterns of globalization along three dimensions (trade, migration, and finance) at the level of individual states in the U.S. We combine data from a variety of sources to provide a rich picture of the evolution of globalization in the individual states over the past two decades. While the data available to us are fragmentary, they do enable us to construct a reasonable profile of the diversity of international linkages at the state level, and to show how diversity has evolved over time. An interesting finding in the paper is that states that are diversified in terms of their trade patterns are not necessarily very diversified in terms of the origins of their immigrants. This is even more the case when it comes to financial linkages, but that is more a reflection of the limited state-level data on foreign financial and banking activity.

The review of international linkages in this paper suggests several avenues for further research. To begin with, the linkages we examine are asymmetric. On the international trade side, we have reasonably good data on state exports but know relatively little about state imports. Likewise, we have solid data on the origins of immigrants to different states, but we know less about where state residents emigrate. Even with the limitations imposed by international banking data, it might be interesting to complement the data on foreign banking operations within the U.S. with the overseas operations of U.S. banks.

Second, it is worth asking why we should care about diversity of trade patterns, the extent of that diversity, and so on. From the perspective of economic theory, what we are ultimately interested in is the volatility of per capita consumption. Even in the presence of highly specialized trade patterns, it may be possible for the citizens of individual states to insure by other means, for example, by holding diversified portfolios of assets. Addressing this question in a satisfactory manner would require more detailed data on the portfolio positions of the citizens of individual states.

\section{REFERENCES}

Agosin, Manuel R., Roberto Alvarez, and Claudio Bravo-Ortega. (2012) "Determinants of Export Diversification Around the World: 1962-2000,” World Economy, 35, 295-315.

Amiti, Mary and Anthony J. Venables. (2002) “The Geography of Intra-Industry Trade," in Peter John Lloyd and Hyun-Hoon Lee (eds.), Frontiers of Research in Intra-Industry Trade. Palgrave Macmillan: Basingstoke, UK, pp. 87-106.

(C) Southern Regional Science Association 2017. 
Autor, David H., David Dorn, and Gordon H. Hanson. (2013) "The China Syndrome: Local Labor Market Effects of Import Competition in the United States," American Economic Review, 103, 2121-2168.

Bandyopadhyay, Subhayu, Cletus C. Coughlin, and Howard J. Wall. (2008) "Ethnic Networks and U.S. Exports," Review of International Economics, 16, 199-213.

Bhagwati, Jagdish and Alan S. Blinder. (2009) Offshoring of American Jobs: What Response from U.S. Economic Policy? MIT Press: Cambridge, MA.

Borjas, George J. (2014) Immigration Economics. Harvard University Press: Cambridge, MA.

Braun, Denny. (1988) "Multiple Measures of U.S. Income Inequality," Review of Economics and Statistics, 70, 398-405.

Cadot, Olivier, Céline Carrère, and Vanessa Strauss-Kahn. (2011) "Export Diversification: What's Behind the Hump?," Review of Economics and Statistics, 93, 590-605.

Cassey, Andrew J. (2011) "State Foreign Export Patterns," Southern Economic Journal, 78, 308-329.

. (2009) "State Export Data: Origin of Movement vs. Origin of Production," Journal of Economic and Social Measurement, 34, 241-268.

Claessens, Stijn, Omar Hassib, and Neeltje van Horen. (2015) "The Role of Foreign Banks in Trade," mimeo, Federal Reserve Board, Maastricht University, De Nederlandse Bank.

Clemens, Michael A. (2011) "Economics and Emigration: Trillion-Dollar Bills on the Sidewalk?" The Journal of Economic Perspectives, 25 (3), 83-106

Collins, Susan M. (ed.) (1998) Imports, Exports, and the American Worker. Brookings Institution Press: Washington, DC.

Coughlin, Cletus C. and Patricia S. Pollard. (2001) "Comparing Manufacturing Export Growth Across States: What Accounts for the Differences?," Federal Reserve Bank of St. Louis Review, 83, 25-40.

Coughlin, Cletus C. and Philip A. Cartwright. (1987a) "An Examination of State Foreign Export Promotion and Manufacturing Exports," Journal of Regional Science, 27, 439-449.

. (1987b) "An Examination of State Foreign Exports and Manufacturing Employment," Economic Development Quarterly, 1, 257-267.

Crandall, Robert W. (1993) "Manufacturing on the Move," Brookings Institution Press: Washington, DC.

Cronovich, Ron and Ricardo Gazel. (1998) "Do Exchange Rates and Foreign Incomes Matter for Exports at the State Level?," Journal of Regional Science, 38, 639-657.

Erickson, Rodney A. and David J. Hayward. (1991) "The International Flows of Industrial Exports from U.S. Regions," Annals of the Association of American Geographers, 81, 371-390.

Espinosa, Kristin and Douglas Massey. (1997) "Undocumented Migration and the Quantity and Quality of Social Capital,” Soziale Welt, Sonderband (special edition) 12, 141-162.

(C) Southern Regional Science Association 2017. 
Fringer, Michael J. and Mordechai E. Kreinin. (1979) “A Measure of 'Export Similarity' and its Possible Uses,” Economic Journal, 89, 905-912.

Funke, Michael and Ralf Ruhwedel. (2001) "Product Variety and Economic Growth: Empirical Evidence for the OECD Countries," IMF Staff Papers, 48, 225-242.

Gould, David M. (1994) "Immigrant Links to the Home Country: Empirical Implications for U.S. Bilateral Trade Flows," Review of Economics and Statistics, 76, 302-316.

Grogger, Jeffrey and Gordon H. Hanson. (2011) "Income Maximization and the Selection and Sorting of International Migrants," Journal of Development Economics, 95, 42-57.

Gutierrez de Pineres, Sheila Amin and Michael J. Ferrantino. (1997) "Export Diversification and Structural Change: Some Comparisons for Latin America," SSRN Working Paper 36231.

Hummels, David and Peter J. Klenow. (2005) "The Variety and Quality of a Nation's Exports," American Economic Review, 96, 704-23.

Herander, Mark G. and Luz A. Saavedra. (2005) "Exports and the Structure of Immigrant-based Networks: The Role of Geographic Proximity," Review of Economics and Statistics, 87, $323-335$.

Imbs, Jean and Romain Wacziarg. (2003) "Stages of Diversification," American Economic Review, 93, 63-86.

Kletzer, Lori G. (2002) Imports, Exports and Jobs: What Does Trade Mean for Employment and Job Loss? Upjohn Press: Kalamazoo, MI.

Klinger, Bailey, and Daniel Lederman. (2004) "Discovery and Development: An Empirical Exploration of 'New' Products," World Bank Policy Research Working Paper 3450: Washington, D.C.

Mayda, Anna Maria. (2010) "International Migration: A Panel Data Analysis of the Determinants of Bilateral Flows," Journal of Population Economics, 23, 1249-1274.

McCallum, John. (1995) "National Borders Matter: Canada-U.S. Regional Trade Patterns," American Economic Review, 85, 615-623.

Niepmann, Friederike and Tim Schmidt-Eisenlohr. (2016) "No Guarantees, No Trade: How Banks Affect Export Patterns," Federal Reserve Bank International Finance Discussion Paper 1158: Washington, D.C.

Peri, Giovanni and Francisco Requena-Silvente. (2010) "The Trade Creation Effect of Immigrants: Evidence from the Remarkable Case of Spain," Canadian Journal of Economics, 43, 1433-1459.

Sapir, Andre. (1996) “The Effects of Europe's Internal Market Program on Production and Trade: A First Assessment," Weltwirtschaftliches Archiv, 132, 457-475.

(c) Southern Regional Science Association 2017. 


\section{APPENDIX: DATA SOURCES AND DEFINITIONS}

State Exports: U.S. states' data are available on an annual basis from 1997. Export flows by trading partners and by product for all 50 states and the District of Columbia are reported by the World Institute for Strategic Economic Research (WISER). We compute export weights based on export flows from each state to each trading partner using the following weighting scheme: $\emptyset_{c, s, t}^{x}=x_{c, s, t} / \sum_{C=1}^{C_{s, t}^{X}} x_{c, s, t}$, which shows the exports to country $c$ as a share of the total exports of state $s$ at date $t$.

Gross Domestic Product (GDP): Output for each country and global GDP data are from the International Monetary Fund's World Economic Outlook database.

Gross State Product (GSP) data are from the Bureau of Economic Analysis, which are available from 1997 onwards.

Immigration data: States' foreign-born immigrant data are from the American Community Survey (ACS) for the period 2005 to present. U.S. Census Bureau decennial survey data are used for the years 2000 and 1990. The ACS is sent to a small percentage of the U.S. population, and collects detailed information on the characteristics of U.S. population and housing. Since ACS data are collected every year, rather than once every ten years, they provide more current estimates. The Census Bureau expanded the ACS to full sample size for housing units in 2005. Estimates prior to 2005 are available but do not contain the level of detail needed for our analysis.

World Population: Population data are from the United Nations' World Population Prospects.

Foreign Banking Entities: Data on foreign banking entities are from the Federal Reserve Board of Governors. These are reported quarterly and available from 1997. Data includes information on the location of foreign financial institutions and type of institutions (i.e., whether it is a representative office with no assets or a branch with U.S. assets).

U.S. States' Population: Data on state-level population are from the Bureau of Economic Analysis.

Real Personal Consumption Expenditures per Person (Per capita RPCE): Data on statelevel RPCE is from the U.S. Bureau of Economic Analysis. Per capita RPCE is computed by dividing RPCE for each state with the corresponding state population data.

Tax Burden: These are tax burdens imposed on residents by states. These are state taxes per capita, which include both state and local taxes reported by the U.S. Tax Foundation.

Expenditures on Foreign Travel by U.S. Residents as a Share of Services PCE: Data on personal consumption expenditures are from the Bureau of Economic Analysis.

Expenditures in the U.S. by Non-residents as a Share of Services PCE: Data on expenditures by non-U.S. residents are from the Bureau of Economic Analysis. 
Table 4: Export Categories Used in Measuring Export Diversification

\begin{tabular}{|c|c|c|c|}
\hline & $\begin{array}{l}\text { Exports by product } \\
\text { (NAICS 3-digit Code) }\end{array}$ & $\begin{array}{l}\text { Gross State Product by } \\
\text { product (NAICS 3-digit code) }\end{array}$ & $\begin{array}{l}\text { Consolidated } \\
\text { category }\end{array}$ \\
\hline 1 & Food (311) & \multirow{2}{*}{$\begin{array}{l}\text { Food, beverages and tobacco } \\
\text { products }\end{array}$} & \multirow{2}{*}{$\begin{array}{l}\text { Food, beverages and } \\
\text { tobacco products } \\
(311+312)\end{array}$} \\
\hline 2 & Beverages and tobacco (312) & & \\
\hline 3 & Textile mills (313) & \multirow[t]{2}{*}{ Textile and textile product mills } & \multirow{2}{*}{$\begin{array}{l}\text { Textile and textile } \\
\text { product mills } \\
(313+314)\end{array}$} \\
\hline 4 & Textile product mills (314) & & \\
\hline 5 & Apparel (315) & \multirow{2}{*}{$\begin{array}{l}\text { Apparel, leather and allied } \\
\text { products }\end{array}$} & \multirow{2}{*}{$\begin{array}{l}\text { Apparel, leather and } \\
\text { allied products } \\
(315+316)\end{array}$} \\
\hline 6 & Leather and allied products (316) & & \\
\hline 7 & Wood products (321) & Wood products & Wood products \\
\hline 8 & Paper (322) & Paper & Paper \\
\hline 9 & $\begin{array}{l}\text { Printing and related support activities } \\
(323)\end{array}$ & $\begin{array}{l}\text { Printing and related support } \\
\text { activities }\end{array}$ & $\begin{array}{l}\text { Printing and related } \\
\text { support activities }\end{array}$ \\
\hline 10 & Petroleum and coal products (324) & Petroleum and coal products & $\begin{array}{l}\text { Petroleum and coal } \\
\text { products }\end{array}$ \\
\hline 11 & Chemicals (325) & Chemical products & Chemical products \\
\hline 12 & Plastics and rubber products (326) & Plastics and rubber products & $\begin{array}{l}\text { Plastics and rubber } \\
\text { products }\end{array}$ \\
\hline 13 & Nonmetallic mineral products (327) & Nonmetallic mineral products & $\begin{array}{l}\text { Nonmetallic mineral } \\
\text { products }\end{array}$ \\
\hline 14 & Primary metals (331) & Primary metals & Primary metals \\
\hline 15 & Fabricated metal products (332) & Fabricated metal products & $\begin{array}{l}\text { Fabricated metal } \\
\text { products }\end{array}$ \\
\hline 16 & Machinery (333) & Machinery & Machinery \\
\hline 17 & $\begin{array}{l}\text { Computers and electronic products } \\
\text { (334) }\end{array}$ & $\begin{array}{l}\text { Computer and electronic } \\
\text { products }\end{array}$ & $\begin{array}{l}\text { Computer and } \\
\text { electronic products }\end{array}$ \\
\hline 18 & $\begin{array}{l}\text { Electronic equipment, appliances and } \\
\text { components ( } 335)\end{array}$ & $\begin{array}{l}\text { Electrical equipment and } \\
\text { appliance manufacturing }\end{array}$ & $\begin{array}{l}\text { Electrical equipment } \\
\text { and appliance } \\
\text { manufacturing }\end{array}$ \\
\hline 19 & Transportation equipment (336) & $\begin{array}{l}\text { Motor vehicles, bodies, trailers } \\
\text { and parts and other } \\
\text { transportation equipment }\end{array}$ & $\begin{array}{l}\text { Transportation } \\
\text { equipment }\end{array}$ \\
\hline 20 & Furniture and related products (337) & Furniture and related products & $\begin{array}{l}\text { Furniture and related } \\
\text { products }\end{array}$ \\
\hline 21 & Miscellaneous manufacturing (339) & Miscellaneous manufacturing & $\begin{array}{l}\text { Miscellaneous } \\
\text { manufacturing }\end{array}$ \\
\hline
\end{tabular}


Table 5: Summary of Descriptive Statistics for Data Used in Regression Analysis in Table 1

\begin{tabular}{|c|c|c|c|c|c|c|}
\hline & Obs. & Mean & Median & Min & Max & $\begin{array}{l}\text { Std. } \\
\text { Dev }\end{array}$ \\
\hline Diversity of exports by destination & 900 & 0.129 & 0.106 & 0.025 & 0.631 & 0.079 \\
\hline Diversity of exports by product & 900 & 0.159 & 0.120 & 0.039 & 0.825 & 0.121 \\
\hline Diversity of foreign bank assets & 361 & 0.775 & 0.999 & 0.109 & 1.000 & 0.292 \\
\hline Diversity of foreign-born population & 471 & 0.124 & 0.090 & 0.015 & 0.530 & 0.110 \\
\hline Diversity of GSP-production base & 850 & 0.114 & 0.084 & 0.015 & 0.621 & 0.094 \\
\hline Real PCE per capita & 900 & 30.911 & 30.328 & 19.141 & 43.995 & 4.729 \\
\hline Per capita state taxes & 800 & 3.881 & 3.669 & 2.052 & 7.869 & 0.986 \\
\hline $\begin{array}{l}\text { Expenditure in the U.S. by nonresidents as } \\
\text { a share of services PCE }\end{array}$ & 800 & 1.315 & 1.065 & 0.240 & 12.997 & 1.083 \\
\hline $\begin{array}{l}\text { Expenditure on foreign travel by U.S. } \\
\text { residents as a share of services PCE }\end{array}$ & 800 & 2.065 & 0.639 & 0.111 & 62.218 & 6.521 \\
\hline
\end{tabular}

(c) Southern Regional Science Association 2017. 